جامعـة نيويورلك أبوظـبي

世 NYU $\mid$ ABU DHABI

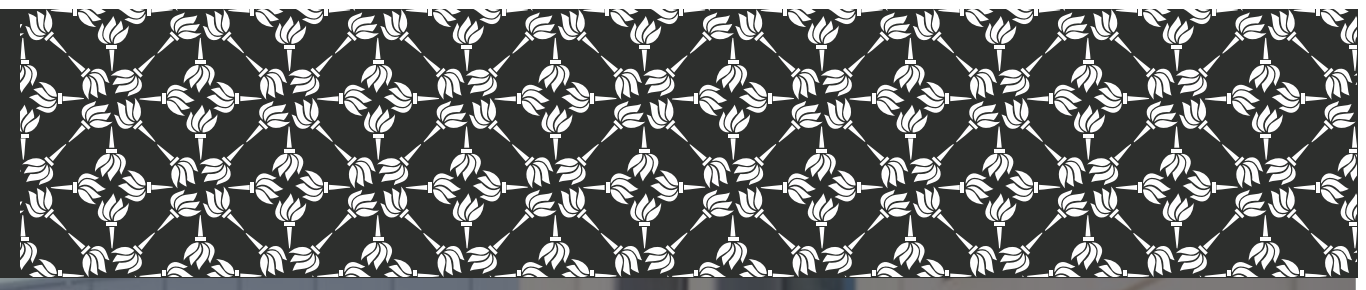

\title{
Trade and Political Fragmentation on the Silk Roads: The Economic Effects of Historical Exchange between China and the Muslim East
}

Lisa Blaydes, Christopher Paik

Working Paper \# 0033

December 2019 


\title{
Trade and Political Fragmentation on the Silk Roads: The Economic Effects of Historical Exchange between China and the Muslim East
}

\author{
Lisa Blaydes* Christopher Paik ${ }^{\dagger}$
}

Word Count: 9,831

\begin{abstract}
The Silk Roads stretched across Eurasia, connecting East and West for centuries. At its height, the network of trade routes enabled merchants to travel from China to the Mediterranean Sea, carrying with them high-value commercial goods, the exchange of which encouraged urban growth and prosperity. We examine the extent to which urban centers thrived or withered as a function of shocks to trade routes, particularly political fragmentation along natural travel paths. We find that political fragmentation along the roads to Aleppo and historic Chang'an - major terminus locations for cross-regional trade - damaged city growth. These conclusions contribute to our understanding of how a pre-modern international system operated through an examination of exchange between the two most developed world regions of the medieval and early modern periods, China and the Muslim East.
\end{abstract}

\footnotetext{
*Department of Political Science, Stanford University

${ }^{\dagger}$ Division of Social Science, New York University Abu Dhabi
} 
The Silk Roads were among the world's most important historical commercial routes, connecting economic interests in prosperous areas like China and the Middle East for centuries. Commodities traded on these trans-Eurasian routes included silk, coral, pearls, glass, jade, gems, perfumes, and incense. During the medieval and early modern periods, ChineseMiddle Eastern trade was both a reflection and driver of economic prosperity with scholars suggesting that the Silk Roads constituted a cross-regional economy (Buzan and Little 1994) that played a crucial, connecting role in an emerging "world system" (Abu-Lughod 1989).

Scholars focused on historical Silk Roads trade emphasize the costs and dangers associated with overland exchange (e.g., Steensgaard 1973; Millward 2007; Frankopan 2016). Scholarship in this vein suggests that political fragmentation may have been a hindrance to gains from cross-cultural trade. Fragmented political authority created opportunities for state actors to demand tolls and taxes from merchants; uncertain and unstable political control increased the possibility for brigands to predate on travelers, further raising the cost of exchange. We home in on historical overland trade between China and the Middle East to show the economic effects of political shocks on one important measure of economic development - city size. Merchants, including those who traded foreign luxury goods, were among the wealthiest urban dwellers of the medieval and early modern periods. We find that greater political fragmentation on the roads to Aleppo and historic Chang'an (contemporary Xi'an) - major Silk Road terminus points - damaged gains from trade since traders and their agents had to contend with uncertainty and multiple tariffs on their route. These results persist even after controlling for both city and time fixed effects, among other control variables, as well as the Chinese tribute system, which created commercial, diplomatic and security ties between imperial China and smaller, surrounding polities.

The empirical results we present speak to the question of how political fragmentation and jurisdictional uncertainty impact the gains from cooperation. Scholars have long suggested 
that a well-ordered world is conducive to trade and cross-cultural exchange. ${ }^{1}$ Simmons (2005, 843) argues that the question of "who is formally sovereign over what geographical space" is a first-order concern where ambiguity regarding rules and legal protections reduces the number of cross-border transactions. Epstein $(2000,8)$ finds that jurisdictional fragmentation increased "negotiation, enforcement, and exaction costs" associated with historical trade. For example, fragmentation created potential for actors like the medieval "robber barons" (or "robber knights") to impose high taxes and tolls on rivers and roads that were located in their territories. Cox $(2017,726)$ defines the phenomenon more generally as intra-route fragmentation — the split in governing authority along a single shipping route, a situation which leads to over-taxation of the common pool of merchants. ${ }^{2}$ Our analysis provides an empirical assessment of how barriers to trade hindered pre-modern economic development.

These ideas contrast with research that has suggested political fragmentation - due to competing war-prone states (e.g., Tilly 1990), the effects of feudalism on executive constraint (e.g., Blaydes and Chaney 2013), or the existence of merchants' exit options (e.g., Cox 2017) — has had positive effects on institutional development in Europe. ${ }^{3}$ In Asia, political

\footnotetext{
${ }^{1}$ International relations scholars have found that territorial disputes hinder economic ex-
} change. For example, empirical evidence suggests that conflict disrupts trade (Anderton and Carter 2001) and there are large and persistent negative impacts of war on economic welfare (Glick and Taylor 2010).

${ }^{2}$ Schleifer and Vishny (1993) describe a state road as the most basic of governmentproduced goods; government officials have the right to restrict access to that good but when state authority is low, overtaxing via corruption can slow economic development. Dincecco (2010) examines institutional fragmentation and associated proliferation of customs tariffs within states along the Rhine in the 18th and 19th centuries.

${ }^{3}$ Schiedel (2019) provides a robust synthesis of the argument that fragmentation (a term he uses interchangeably with "polycentrism") was essential for economic growth and develop- 
fragmentation - when it did occur — failed to generate forms of executive constraint and may have hindered the ability of societies to benefit from cross-cultural exchange. Our findings contribute to political economy research focused on the historical development of Asia (e.g., Kang 2010; Rosenthal and Wong 2011; Park 2012; Dincecco and Wang 2018), and suggest the ways that economic development in Asia followed a different path than that which occurred in Europe.

Most generally, this paper speaks directly to the question of how international systems operate - and does so in a way that increases our understanding of pre-modern international systems operating outside of the European context. ${ }^{4}$ Influential scholars in international relations have sought to draw attention to "system effects" in international history, arguing that systems are characterized by forms of interconnectedness where "the fates of the units and their relations with others are strongly influenced by interactions at other places and at earlier periods of time" (Jervis 1997, 17). Theoretical and empirical explorations of these issues have focused on the emergence of the system of sovereign states in Europe during the early modern period (Spruyt 1994) and the effects of the Chinese tributary regime on ment. In particular, he argues that in Europe after the fall of the Roman Empire "enduring polycentrism both within and between states...sustained development-friendly institutional arrangements, encouraged overseas exploration and expansion, and allowed a culture of innovation and bourgeois values to take hold" (Schiedel 2019, 503).

${ }^{4}$ There is relatively little scholarship that addresses the question of how international systems function, particularly in the past, or the conditions under which they these systems wither or flourish. This intellectual blind spot is even more acute for regions outside of Europe as scholarly conceptions of the international system have been biased and based on the characteristics of the European experience (Buzan and Little 1994). 
international system in the East Asian context (Kang 2010; 2013). ${ }^{5}$ We focus on the Silk Roads as an international system - one made up of a variety of interconnected actors including merchants, artisans, bandits as well as states and their agents - in order to contribute to scholarly understanding of historical global encounters and their effects.

\section{The Global Economic Order before Western Hege- mony}

Existing scholarly work suggests the lack of a global economic hegemony before the 18th century. ${ }^{6}$ At the start of the early modern period, China was arguably the greatest economic power in the world with a population of more than 100 million, a productive agricultural sector, and craft industries superior to those found in other parts of Eurasia (Atwell 1998). ${ }^{7}$ As European markets grew in importance, demand increased for Asian perfumes, spices, and silks. ${ }^{8}$ Many of these luxury goods traveled through Persia and the Levant, eventually arriving in Aleppo. This section discusses the conditions under which trade routes connected

\footnotetext{
${ }^{5} \mathrm{~A}$ growing and influential literature explores the determinants of historical Chinese political hegemony in Asia (Lee 2016) as well as the concept of sovereign autonomy in the East Asian context (Park 2017).

${ }^{6}$ Abu-Lughod (1989, 364-365) argues that the world economic system in the medieval period lacked a single hegemon but instead there existed multiple core powers in a nonhierarchical, interdependent world economic system.

${ }^{7}$ Frank $(1998,324)$ writes that until at least 1700, there was nothing "exceptional" about Europe other than its relative marginality and "correspondingly minor role in the world economy."

${ }^{8}$ See Blaydes and Paik (2016) for one perspective regarding how the Holy Land Crusades spurred urban growth associated with demand for Eastern commercial products.
} 
urban areas, including how political fragmentation along travel paths may have hindered the gains from exchange.

\subsection{Eurasia's Economic Distribution of Power}

One key challenge associated with identifying the historical global distribution of economic power relates to measurement. Influenced by scholarship in the field of political economy, we adopt city size as a proxy for economic development in the pre-industrial period. De Long and Shleifer $(1993,675)$ suggest that the population of pre-industrial European cities serves as the best available indicator of economic prosperity, since urban areas relied on high levels of agricultural productivity and specialization. Acemoglu et al. (2002) present both cross-sectional and time-series evidence suggesting a close empirical association between urbanization and income per capita for cities around the world in the pre-industrial period. Stasavage (2014) uses city size as a proxy for economic flourishing in his examination of comparative economic development in pre-modern Europe.

City population estimates from Africa, Europe and Asia suggest that between 1100 and $1800 \mathrm{CE}$, the largest cities in the world were located primarily in China and the Middle East. ${ }^{9}$ Indeed, Eurasia's urban 'center of gravity' for much of the last millennium was located in contemporary Iran. ${ }^{10}$ By 1800, however, the cities of Northwestern Europe increasingly became among the world's largest, alongside Asian cities. ${ }^{11}$ Kupchan $(2012,3)$ argues that the world's center of influence shifted from Asia and the Mediterranean to Europe by the

\footnotetext{
${ }^{9}$ See Figure S1 on page S-10 of the Appendix.

${ }^{10}$ See page S-2 for data description and Table S1 on page S-3 of the Appendix for more details.

${ }^{11}$ After that point, the cities of Western Asia, long favored as a result of their position as a "commercial and migratory turntable" (Frank 1998, 75), became less prominent than in previous periods; areas of Central Asia which used to be important crossroads "ceased
} 
18th century with important implications for the ability of the West to use "its power and purpose to anchor a globalized world."

\subsection{Trade, Cities, and Political Order}

One reason that the Middle East and Central Asia thrived for so long relates to the central location of the region with regard to trade routes. Among the most prominent of these routes were the Silk Roads. The term "Silk Road" refers to "all the different overland routes leading west out of China through Central Asia to Syria and beyond" (Hansen 2012, 235). Christian $(2000,3)$ defines the Silk Roads as "the long- and middle-distance land routes by which goods, ideas, and people were exchanged" between major regions of Eurasia.

Trade was an important driver of prosperity in urban areas. Merchants engaged in longdistance trade were among the wealthiest residents of major Eurasian cities. Gilbar (2003, 1) argues that long-distance traders were "at the very top of the ladder of the commercial community" given the size and scope of their economic activities as well as their possession of considerable liquid wealth. Frankopan $(2016,144)$ finds that merchants made fortunes meeting demand for luxury goods from China and India. Scholarship focused on fifteenth century Cairo suggests that the two-hundred most important merchants each possessed millions of gold pieces (Labib 1970, 77). Court records from Bursa in the late fifteenth century suggest that the wealthiest merchants in the city were those involved in either the spice or silk trade (Inalcik 1994, 344-345).

Yet trade ties could be disrupted, damaging prospects for merchants. Caravan routes could be disturbed by war, political change, and Bedouin incursions (Constable 2010). How did shocks to trade impact the growth of cities in China and the Muslim East? And how did the rise of the Western international order damage these historical trade ties? Blaydes and Paik (2020) find that proximity to historical Muslim trade routes was positively associated to be so central to world history" as the "world historical center of gravity shifted outward, seaward, and westward" (Frank 1992, 44). 
with urbanization in 1200 but not in 1800. In other words, Middle Eastern and Central Asian cities - long beneficiaries of locational centrality between Europe and Asia — declined as Europeans found alternative routes to the East and opened new trade opportunities in the New World.

In this paper, we focus on another disruption to trade - political fragmentation - that damaged economic growth along major land routes connecting Western to Eastern Asia. Why focus on Asia? Beyond the need to de-center world historical studies away from a focus on Europe, there are theoretical and empirical benefits from such an approach. First, as discussed in the previous section the Eurasian urban of center of gravity was located in Asia. The Middle East and China — despite important differences of religion and philosophy — shared historical parallels, including their vulnerability to external actors, like nomadic tribesmen (Harris 1993, 23). In addition, Park $(2012,191)$ writes that, "the history of contact and exchange between China and the Islamic world offers one of the most remarkable cases of pre-European encounter because it involves tremendous wealth, transformative ideas, and great power."

Second, we pick up on threads within the existing literature which suggest that China served as the global economic heavyweight with which other cultures sought to trade. According to Frank $(1998,111)$, China was "unrivaled" in its production of luxury consumer goods like porcelain, ceramics, and silks. Indeed, China has been described as exhibiting "outstanding absolute and relative productivity in manufactures" (Frank 1998, 127). ${ }^{12}$ As Europe become wealthier, there was a strong interest in acquiring Chinese products. Frank

\footnotetext{
${ }^{12}$ India also produced important and valued goods. But given the predominance of sea trade opportunities — and our interest in overland trade — we are focused primarily on trade with China.
} 
(1998, 116-117) goes as far as to argue that "the entire world economic order was - literally - Sinocentric" until the 18 th century. ${ }^{13}$

Even if we take Frank's position on these issues to be extreme, relatively little scholarship has sought to understand the effects of political fragmentation outside of Europe. Much has been written about the benefits of political fragmentation in Europe where fragmentation is thought to have created conditions ripe for limited government and, eventually, economic development. ${ }^{14}$ While an influential literature has suggested that forms of political fragmentation has been directly or indirectly good for economic development (e.g., Tilly 1990; Blaydes and Chaney 2013; Cox 2017), fragmentation also damaged the gains to trade (e.g., Epstein 2000; Simmons 2005). ${ }^{15}$ In Eastern and Western Asia, growth-promoting institutions, like parliaments, were slow to develop; we consider the conditions which encouraged

${ }^{13}$ Sharman (2019) concurs, arguing that the dominance of European powers over Asian ones starting in the 18th century represents a historical anomaly.

${ }^{14}$ Fragmentation is thought to have been a common feature of European history. Schiedel (2019) has argued that the emergence of the Roman Empire - Europe's longest experience with imperial rule — was a historical anomaly. As Rosenthal and Wong (2011) point out, empire under Chinese dominance was the norm in East Asia, on the other hand.

${ }^{15}$ At least three sets of arguments seek to link political fragmentation with European institutional development. Tilly (1990) focuses on the impact of competition between small, war-prone polities on the development of national states. Blaydes and Chaney (2013) argue that the decentralized forms of political control associated with feudal institutions had positive impacts on the emergence of executive constraint. Cox (2017) argues that political fragmentation — which provided exit options for merchants - combined with self-governing cities and parliaments to facilitate forms of executive liberty. Also see Jones (2003) for more on how fragmentation improved merchant options. 
or discouraged economic exchange and development outside of the European experience. In this paper, we argue that political fragmentation hindered the exchange of goods, hurting economic prosperity — and that the most appropriate place to test this argument is in premodern Asia where the effects of fragmentation were not confounded by growth-promoting institutions, as developed in Europe.

\subsection{Causes and Effects of Political Fragmentation}

It is no coincidence that two of the most famous explorers of the medieval period - Ibn Battuta of Tangier and Marco Polo of Venice - made their famous cross-regional travels during the late 13 th and early 14 th centuries. In the century after the Mongols created the largest land empire in world history, political stability in Western Asia facilitated travel of people, goods, and ideas. Their characterizations of long-distance, cross-regional travel suggest the relative safety of their journeys. The most important challenges that they faced were related to extreme weather, not the dangers of travel. Indeed both travelers describe the relative wealth of the cities they visited and the hospitality of the people they met along the way.

But the movement of travelers, including merchants, might be disrupted for a variety of reasons, many of which were related to political fragmentation. In particular, periods of incomplete or uncertain political control could be highly disruptive to trade. For example, tribal warfare posed a security threat to traders (Abu-Lughod 1989, 158). According to Curtin (1984, 93-94), "to take a caravan through an uncontrolled nomad country would have been dangerous in the best of circumstances." In Yunnan and Uighur areas, trade routes were disrupted when border areas became insecure (Cinar et al. 2015); in the Caucasus, unrest and political instability made travel "impracticable" whereas pacification of these regions

allowed overland trade routes to be used with regularity (Matthee 1994, 740). According to Harris $(1993,22)$, "the emergence of small warring kingdoms...made the East-West highway more dangerous and difficult and populations along the route began to decline." 
Beyond that, traversing a number of different polities might also lead merchants to incur multiple tolls as a result of political fragmentation. Individual merchants were often required to make payment for safe passage upon entering the territory of another state. As a result, "protection rent and tribute are natural and necessary concepts" for understanding premodern trade (Steensgaard 1973, 17). Long-distance traders who transported goods over land were concerned about being subject to taxes and fees (Frankopan 2016, 220) in addition to "customs duties...(and) extortion" (Steensgaard 1973, 60). Cinar et al. (2015) argues that prevailing rates of tax or tariff determined if trade flourished. ${ }^{16}$ While even a fully organized state could not promise safety for travelers, state tax collectors were considered preferable to highway robbers since tax men were more predictable and had a larger interest in maintaining trade into the future (Steensgaard 1973, 62-67). ${ }^{17}$

Beyond the payment required by "potentates through whose territories" merchant caravans passed, nomadic people whose territories were traversed could also make demands (Goiten 1967, 279). Imperial states, like the Mughuls and Ottoman, levied more predictable taxes on travelers, but merchants were also concerned with "highway robbers" who demanded payment for serving as an "armed escort" through hinterland areas (Barendse 2000, 217). Traders along the Russian overland routes were concerned about safety, "high tolls and poor security," all of which could negatively impact trade (Matthee 1994, 752). Peaceful relationships between empires facilitated safe passage in border regions, leading to a flourishing of Middle Eastern trade with Mediterranean areas (Rankbar and Manesh 2016). The

\footnotetext{
${ }^{16}$ Historians have suggested that state-imposed tariffs in Persian cities, for example, varied across politics and could range from 4 percent in some localities to 16 percent in other locations (Cinar et al. 2015). In Russian areas, merchants were often required to pay transportation taxes as well an ad-valorem tax (Mattee 1994, 752).

${ }^{17}$ There was also a strong tendency to stick with agreed upon customs duties and tariffs, especially in Islamic areas (Steensgaard 1973, 62).
} 
importance and profitability of the Silk Roads "waxed and waned," at least in part, as a function of the political stability on the edges of agrarian civilizations of China, India, Iran and Mesopotamia (Christian 2000,6).

Phillips and Sharman (2015) argue that large empires, on the other hand, generated systems of authoritative political control that helped to coordinate market activities across long distances. Christian $(2000,6)$ finds that "when the agrarian civilizations or pastoralist empires dominated large sections of the Silk Roads, merchants traveled more freely, protection costs were lower, and traffic was brisk." How did states matter in supporting trade? In historical Persia, for example, specialized highway police were stationed at regular intervals along trade routes in order to maintain order; they were paid a modest, fixed duty per beast of burden that passed (Steensgaard 1973, 68). In some cases, local governors could even be held responsible if a traveler was robbed and stolen goods could not be recovered (Steensgaard 1973, 69). Interior security and a well-functioning toll system contributed to prosperity for the Persian economy (Rankbar and Manesh 2016).

Scholars have struggled to explain the many and complex causes of political fragmentation and jurisdictional uncertainty. ${ }^{18}$ At some times, large imperial units would take control of vast swaths of territory. The process by which this emerged often involved "consolidating groups into a single confederation" which might spread across the steppe to include new

${ }^{18}$ Abramson (2017) provides a theoretical and empirical narrative regarding the formation of states in Europe and associated European political fragmentation between 1100 and 1790 . He finds that small political units persisted throughout his period of study but tended to be more common when weather-related shocks aided the growth of cities and towns. The situation in Europe - where cereal production was a driver of economic conditions contrasts with the Central Asian context. In Central Asia, geographies of desert, plateau, and mountain pasture made livestock production more prominent than cereal production, especially when compared to Europe. Schiedel $(2019,274)$, for example, emphasizes the 
territories and peoples (Rogers 2007, 258). Rogers $(2012,206)$ argues that there is no obvious explanation for when and why successful polities emerge and that polities "emerged, existed, and collapsed in ways that often defy conventional understandings." State formation and collapse, then, can be thought of as caused by a complex set of factors, with a large number of contingencies and, potentially, tied to cyclical patterns (Rogers 2007, 265). ${ }^{19}$ Indeed, part of our approach to causal identification relies on an increasing preponderance of archaeological and historical climate science evidence which suggests that state formation on the Eurasian steppe was a function of exogenous environmental factors.

One factor that might have worked against the negative effects of political fragmentation was the Chinese system of tribute. Zhang (2013) describes the tribute system (chaogong tizhi) as embodying institutions and diplomatic norms that dominated China's relations with the non-Chinese world until the late 19th century. By providing stability and security, Chinese regional hegemony may have operated in a way consistent with hegemonic stability theory which suggests that a hegemonic distribution of power can have positive effects on trade openness (e.g., Krasner 1976; Gilpin 1981; Gilpin 1987). Other scholars, however, have suggested that pre-modern China was not able to create an open trade order (Shu 2012) and that the application of a tributary-system model to historical international relations is deeply problematic (Van Lieu 2017). For example, Perdue (2015) contends that arguments that suggest a systematic Chinese tributary system are misleading given the multiple and complex relationships of trade, diplomacy, and ritual between China and other Asian polities. Our empirical analysis provides evidence testing the effects of changes in tribute status on urban growth.

distinction, arguing that steppe ecologies were primarily inhabited by pastoralists who reared livestock with farming, foraging, and hunting as supplemental economic activities.

${ }^{19}$ Schiedel $(2019,272)$ offers a similar interpretation to state formation of the Central Asian steppe, arguing that "the scale and intensity of imperiogenesis were profoundly shaped by ecological features that drove state formation via intermediating proximate mechanisms." 


\section{Trade Shocks and Prosperity on the Silk Roads}

Between 200 BCE and the beginning of the Common Era, overland trade between China and the eastern Mediterranean polities of the Middle East became a regular occurrence (Curtin 1984, 90). Indeed, the very origins of the Silk Roads have been associated with periods of time when Eurasia was characterized by a relatively small number of large land empires. The emergence of long-distance Eurasian trade was temporally linked to the Han Dynasty's unification of China as well as Han extension of political control into the Xinjiang region. In Western Asia, the Roman Empire extended political control across the Mediterranean. The timing associated with the consolidation of these trade routes suggests a linkage between consolidation of political control in China and the Mediterranean basin. Thus while the location of the Silk Roads may have been determined by geographic features, like "mountain passes, valleys, and springs of water in the desert" (Hansen 2012, 235), the robustness of trade connecting urban areas may have been a function of political factors. In this section, we review some of the existing qualitative evidence regarding how forms of political stability and imperial consolidation impacted cross-cultural exchange in the pre-modern period. If our main conjecture is correct, we should see supportive evidence reflected in the historical literature.

\subsection{Imperial Consolidation and Silk Road Development}

Historians have argued that the Silk Roads enjoyed a "golden age" during the Tang Dynasty (618-907 CE), a period of time that coincided with the Arab conquests and the first two centuries of Islam. Scholars of the early Islamic period have suggested that the advent of Islam was an important force associated with growth in importance of interregional trade (Hodgsen 1974, 65). According to Hodgsen $(1974,65)$, it was during this period that trade became "increasingly determinative of the fate of any given region" and mercantile and bourgeoisie interests strengthened relative to agrarian classes. The Tang Dynasty maintained 
military and commercial connections with Central Asian polities as far west as Persia (Benite 2011).

During this time, trade linking the Middle East and China was economically significant with implications for the growth and development of major urban centers. Caravans of horses and Batrian camels traveled from Mesopotamia to the Iranian plateau and then eastward toward the Oxus after which point routes passed through Kabul and Kashgar (Lombard $1975,218)$.

Political stability associated with large empires created the security zones under which trade might prosper. Curtin $(1984,91)$ argues that the "Tang Dynasty in China and the Abbasid Caliphate of Baghdad...provided imperial umbrellas over most of the trade routes between China and Mediterranean." These favorable conditions, associated with the power of contemporaneously large empires, made it relatively easy for long-distance traders to move across vast areas (Curtin 1984, 105). Under the "long reach of Tang control to the west," many Middle Eastern and European travelers were able to visit China (Curtin 1984, 105). Foreign merchants transformed small, oasis settlements across Central Asia into larger towns and cities (von Glahn 2016, 197). ${ }^{20}$

\subsection{The Mongol Empire and Overland Trade}

The land conquests of the Mongols served as a common shock to both the Eastern and Western parts of Asia. For the Mongols, the rich societies of China, Iran, Iraq, and Anatolia were appealing targets of attack while "little-known, fragmented Europe" was relatively peripheral (Sinor 1999, 40). While much has been written about the destructive aspects of Mongol rule, historians are increasingly painting a more complex picture of the economic impact of the Mongol invasions. Some cities never recovered from the destruction during the conquests, but others saw relatively rapid rebounds in their population (Soucek 2000, 114).

\footnotetext{
${ }^{20}$ Schafer (1963) describes the ways in which foreign trade flourished during this period as
} a result of the relative security of routes and a growing interest in exotic tradeable goods. 
Manz (2011) describes both the destructive elements of the Mongol conquests as well as the new opportunities introduced for artisans and merchants.

One of the most important positive externalities associated with the creation of the Mongol Empire was the establishment of political order over regions that supported overland trade. Curtin $(1984,120)$ writes that "the new rulers united so much of Asia that travelers could move securely under a single authority from the shores of the Black Sea to China." The Mongols built shelters every twenty or thirty miles along roads to assist transport animals as well as to provide guides who specialized in navigating difficult terrains (Weatherford 2004, 220). During this period, Anatolia became more connected to long-distance commercial relations coming from Central and East Asia (Meloy 2011). According to Abu-Lughod (1989, 154), the Mongols created "an environment that facilitated land transit with less risk and lower protective rent." Benite (2011) argues that during this time period, larger numbers of merchants were coming to China compared to ever before, many of them from the Islamic world.

Although the Mongols were a nomadic people, scholars have argued that Mongol rulers "ordered and patronized" economic exchange (Allsen 2001, 191). Manz (2011) suggests that trade was of major interest to the Mongols and that Mongol leaders directly engaged in international trade through commercial partnerships. Caravaners were "prime beneficiaries of the Pax Mongolica" as the formation of a pan-Asian Mongol Empire strongly supported overland, East-West trade (von Glahn 2016, 283). Frankopan (2016, 176) goes as far as to claim that Mongol territorial successes of the 13th century reshaped the monetary system of Eurasia. One scholar summarizes these effects in the following way: "Mongol leaders protected foreign travellers and merchants; established a wide network of relay stations...across their great contiguous land empire; and granted other specific privileges to merchants as well as to religious men, who were often entrepreneurs...medieval writers living during this time reported that these measures were effective in facilitating trade and commerce" (Enkhbold $2019,532)$. 
The break-up of the Mongol Empire may have also hindered forms of economic exchange. Genghis Khan's efforts to divide the empire into parts to pass on to his sons planted the seeds of political instability (Millward 2007, 61). Subsequent internecine conflict among rival Mongol khanates encouraged a greater interest in maritime trade (von Glahn 2016, 283). This reflected a more generalized pattern that during times of political instability in Central Asia, merchants tended to turn to sea routes instead of overland trade (Schottenhammer 2015). This is not to say that the Mongol conquests were not long-term impactful; in the years after the Mongol invasions, China was able to project political power into Central Asia more effectively (Liu 2015, 99). But the lack of a large, overarching land empire covering the Silk Roads may have increased the cost of trade even if the Mongol conquests had distinct and significant additional legacies.

\section{Empirical Analysis}

Thus far, we have discussed a number of factors that might impact the gains from crosscultural, overland trade. While some of these determinants are specific to particular locations, others vary over time and additional factors may reflect an interaction of geographic factors with time. Some of the most significant of these disruptions involved the rise and fall of land empires in Central Asia. Yet the factors that could influence the political stability of Central Asia may be difficult to predict. In this section, our goal is to understand how factors that were disruptive to trade - beyond city-specific or time-specific effects - may have impacted prosperity along the Silk Roads. ${ }^{21}$

\footnotetext{
${ }^{21}$ While a number of studies have looked at commerce in historical China, little work has sought to measure long-term changes in the impact of long-distance trade (Liu 2015, 20).
} 


\subsection{Determining Historical Travel Paths}

One challenge associated with measuring the economic impact of trade and shocks to trade is that sources describe the location of the Silk Roads in different ways. ${ }^{22}$ In this paper we do not attempt to introduce a set of definitive Silk Road corridors or claim to add specific route locations that have hitherto not been described in the existing literature. Our aim is, instead, to establish a link between the cost and ease of travel on the Silk Roads and economic prosperity. For this purpose, we find it useful to look for evidence of how natural travel paths may have been carved, and whether these paths correlate with subsequent changes in economic development. Building on existing work in geography, we suggest that these paths were not endogenous to the Silk Road trade; that is, the path of travel was not chosen with trade or commerce in mind. Rather, we rely on natural geographic features to simulate the route using the strategies described in Frachetti et al. (2017). In doing so, we extend their original study from a particular zone within Inner Asia to a broader Asian sample.

In particular, Frachetti et al. design a GIS algorithm to simulate and identify routes taken by nomads for seasonal travel. This exercise in identifying nomadic travel paths is focused on highland areas at elevations between 750 to 4,000 meters. ${ }^{23}$ According to Frachetti et al., high elevation pathways were an essential part of Silk Road networks, but developed

${ }^{22}$ For example, a UNESCO report published in 2008 claims that there are over 70,000 extant manuscripts for the Chinese section of the Eastern Silk Roads alone, in historical written records from Buddhist monks, Persians and Turkic travellers, Marco Polo, and other 13th century European visitors.

${ }^{23}$ Frachetti et al. (2017) describe this range of elevation to categorize the highlands as different from the lowlands (below 750 meters), which have productive pasture lands that are destroyed by summer heat and aridity, and the upper highlands (above 4,000 meters) that have limited pasture due to permafrost and poor soil quality. 
differently from those in lowland regions, the latter being predicted by terrain-based "least cost" travel algorithms on the basis of "ease of travel" and "connecting dots" between known Silk Road locations. ${ }^{24}$ As a result, the herding paths that predict subsequent Silk Road routes plausibly circumvent endogeneity concerns since existing patterns of urbanization did not impact pastoralists as they sought the best available land for animal grazing. Rather, they were pathways to secluded, rich grasslands that subsequently became corridors of commerce and travel. ${ }^{25}$

Frachetti et al. use their flow accumulation model to create a network of short-distance herding corridors that are highly correlated with Silk Road travel routes. The top panel of Figure 1 shows different characterizations of historical Silk Roads; the bottom panel shows an extension of the Frachetti et al. strategy for identifying nomadic corridors for all of Asia, when we use the same approach and extend the simulation scope to the highlands (750-4,000 meter range) in Asia. ${ }^{26}$

${ }^{24}$ In higher-elevation regions, pastoralists historically migrated with their animals to highland pastures in the summer and travelled back to the lowlands during the winter to maximize food available for their herds. Using seasonal pasture quality and annual herding "flow accumulation" across highlands in Asia, Frachetti et al. create an empirical link between nomadic mobility and Silk Roads. Importantly, when generating the flow model, the authors do not include Silk Road routes or site locations as part of the algorithmic input.

${ }^{25}$ The pastoralist model in Frachetti et al. employs the same flow accumulation algorithm used to simulate flow of water sources through a watershed. Just as water is pulled to a lower elevation by gravity, the model replaces the grass quality for gravity and animal herds for water, and uses the flow accumulation algorithm to calculate how the pasture quality directs flows of seasonally nomadic herders across the highlands.

${ }^{26}$ Specifically, the geographical extent of our analysis spans 25 to 135 degrees longitude, and 5 to 56 degrees latitude. Frachetti et al. focuses on the inner Asian mountain cor- 
Our empirical analysis seeks to assess whether disruption in the Silk Roads, proxied by the historical nomadic migration corridors in the highlands and least-cost routes in low-lying areas, can explain changes in economic development. Our proxy for economic development is urban population for eighty-five East, West and Central Asian cities for the years 1100 to $1800 \mathrm{CE}$, on the fifty-year interval. Our panel data set excludes South and Southeast Asia since trade in those regions was more likely to occur via sea routes rather than the overland routes that are the focus of this analysis. Our data come from Chandler and Fox (1974) and contain all the cities which appear at least once on any of the lists for the world's largest cities across these time periods. ${ }^{27}$ Why operationalize economic growth and trade-related prosperity with city size? Beyond the existing literature in economics endorsing such an approach (De Long and Shleifer 1993; Acemoglu et al. 2002; Stasavage 2014), qualitative historical analysis also draws links between overland Eurasian trade and city growth. For example, Lary $(2012,51)$ argues that trade supported merchants who settled in the cities of Central Asia. Commercial markets created dense networks of exchange which reflected forms of product specialization (Wong 1997, 20). Christian $(2000,9)$ writes that "the urban geography of the Silk Roads...points to the importance of the trans-ecological routes," with important cities, like Kashgar and Bukhara, located on major trade paths.

For our empirical analysis, we simulate Silk Road pathways between each city in our sample and the two Silk Road end points: Aleppo and historic Chang'an. ${ }^{28}$ Chang'an represented a major terminus of overland trade routes in the East (Allsen 2001, 13); Aleppo ridors of Central Asia, those areas mainly connecting present-day Tajikistan, Kyrgyzstan, Kazakhstan, and China.

${ }^{27}$ The Appendix provides further description of city population interval data used in our empirical analysis.

${ }^{28}$ The calculation is based on a combination of both the paths along the nomadic migration corridors, as well as the least-cost path calculated from the city location to the nearest corridor. We confine cities in our sample to those west of Chang'an and east of Aleppo. 
was an "emporium" for Asian goods in the West (Inalcik 1994, 57) and a long-standing destination of overland caravans. In Figure 2 we show the nomadic migration corridors which form the basis for our Silk Road proxy, and the cities in our sample. The simulated pathways connecting each city with Aleppo and Chang'an are also represented on the map. A foundational assumption of our project is that deviations from these natural travel paths are costly for merchants. ${ }^{29}$

\subsection{Measuring Political Fragmentation}

Our main explanatory variable is the degree of political fragmentation merchants faced on the natural travel paths associated with the Silk Roads. In order to assess whether traders encountered different states along their travel paths, we utilize a set of maps from GeaCron, a geo-temporal database which provides state boundaries around the globe for different time periods. $^{30}$ Based on these maps we obtain our main explanatory variable of interest: the number of times that each path crosses different states to Chang'an and to Aleppo. This variable measures the extent of political fragmentation that one would have observed when travelling on the Silk Roads towards the East and the West. We also gather information on whether the departure city was part of a polity identified in GeaCron as well as whether it served as a capital city. ${ }^{31}$

${ }^{29}$ Historians have suggested that for many sections of route, there did not exist good secondary options. For example, for traders departing China along the edge of the Gobi Desert ("beyond the Jade Gate") there did not exist attractive alternative travel paths (Schafer 1963, 13).

${ }^{30}$ See geacron. com for details on how these data were collected.

${ }^{31}$ For coding whether the cities in our data were capital cities or not, we utilize city data from Pierskall et al. (2017). 
It is significant that we code for how many non-state territories that merchants would have traversed on natural travel paths. By identifying areas outside of the purview of state control, or the number of "non-state" territories on the path, this allows us to include an additional dimension to our analysis as travelers in ungoverned areas may have been subject to predation by bandits and nomads. In other words, the mere presence of a state entity should be associated with more security. As discussed, states sought to secure and maintain trade routes by building roads and armed fortresses at stopping points on major routes as well as constructing rest houses to serve merchants and pilgrims (Hanna 1998, 23). In some cases, sophisticated administrative systems with educated bureaucracies eased trade by validating the quality of goods at market and maintaining an extensive road system (Frankopan 2016, 4). Muslim rulers in Central Asia, Persia, and South Asia invested in the maintenance and improvement of trade routes by repairing overland roads, providing security for caravans and quieting tribal peoples who sometimes obstructed commercial traffic (Levi 2010).

One concern that could be raised about our strategy for measuring political fragmentation is that we fail to take into account the endogenous formation of states; in other words, maybe Eurasian land empires were created to encompass profitable trade routes? One advantage of focusing on East, Central, and West Asian cities is that state formation on the Eurasian steppe has come to increasingly be understood as a function of exogenous climatic factors, at least in part because nomadic statecraft has been shown to be sensitive to environmental conditions. This may particularly be the case since there are important links between forms of political authority in Central Asia and transport technologies that support pastoral cultures, especially reliance on horses (Honeychurch 2014).

For example, the sudden rise of Genghis Khan was totally unexpected according to historians (Soucek 2000, 103). Scientists specializing in climate change, however, have found that the timing of the Mongol rise was closely linked to climate anomalies since unusually wet weather was associated with a proliferation of grasses to feed horses as the Mongols moved across the Eurasian steppe (Pederson et al. 2014). Additional studies in climate 
science suggest that the Mongol withdrawal from Hungary in 1242 may also have been a function of unanticipated climactic conditions (Buntgen and Di Cosmo 2016). This perspective is consistent with scholars who have observed that the process by which Eurasian land empires have formed is relatively unpredictable (Rogers 2007; Rogers 2012), suggesting the importance of exogenous conditions.

Figure 3 provides a stylized illustration of our argument and empirical strategy. Merchants from City A seek trade opportunities that allow them to deliver goods to Aleppo and Chang'an. In order for those merchants to engage in commerce, they may need to traverse a number of polities to arrive at their destination. They may also traverse non-state territories, as well as tributary states under the Chinese rule. In this illustration, the solid lines represent independent polities while dotted lines represent independent polities that fall under the Chinese imperial tribute system. The number of state and non-state territories traversed included a large stochastic component related to how exogenous weather and environmental conditions impacted the creation of land empires on the Eurasian steppe.

\subsection{Empirical Strategy}

In order to estimate the impact of political fragmentation on economic prosperity in premodern Asia, we use interval data with population estimates for each city and a generalized maximum log likelihood interval model to obtain coefficient value estimates. ${ }^{32}$ The following equation reflects a panel regression approach, and can be specified as:

\footnotetext{
${ }^{32}$ The coefficient estimates from the interval model can be interpreted in the same way
} as the OLS estimation; see the Appendix page S-2 for a brief explanation and Blaydes and Paik (2020) for more details on specifying the log likelihood function. 


$$
\begin{aligned}
\text { Pop }_{i t}= & \beta_{0}+\beta_{1} \text { Path2Changan }_{i t}+\beta_{2} \text { Path2Aleppo }_{i t}+ \\
& +\mathrm{X}_{i t} \Phi+\sum_{j=1150}^{j=1800} \mathrm{Z}_{i}^{\prime} \mathrm{I}_{t}^{j} \Theta_{j}+\sum_{c} \gamma \mathrm{I}_{i}^{c}+\sum_{j=1150}^{j=1800} \rho_{j} \mathrm{I}_{t}^{j}+\varepsilon_{i t}
\end{aligned}
$$

where $P_{o p}$ it is the natural $\log$ of city population of city $i$ in year $t$, Path2Changan $_{i t}$ and Path2Aleppo $i t$ are our political fragmentation variables, and $X_{i t}$ is a vector of time-varying control variables including the number of non-state territories crossed en route to Chang'an and Aleppo, the capital status and state rule existence of city $i$ in time $t . \sum_{j=1150}^{j=1800} \mathrm{Z}_{i}^{\prime} \mathrm{I}_{t}^{j} \Theta_{j}$ are the city-specific geographic characteristics interacted with time-period fixed effects. Given that city location and their surroundings are paramount to trade and city sizes, these are meant to capture any time-differential effects of geographic variables that determine both the city's access to the Silk Roads and urbanization. They include the distance to the nearest natural migration corridor in the highlands (as simulated in our analysis), distance to the nearest coast, longitude and latitude as well as the elevation mean and standard deviation. Finally, $\sum_{c} \gamma \mathrm{I}_{i}^{c}$ and $\sum_{j=1150}^{j=1800} \rho_{j} \mathrm{I}_{t}^{j}$ are the city and time-period fixed effects, respectively.

On average, a merchant's path intersects with five polities to get to Aleppo and five on the path to Chang'an. ${ }^{33}$ There exists a great deal of variation for cities across time, however. For example, in our sample the maximum number of polities crossed is 16 on the path to Aleppo and 17 to Chang'an. Our main findings are reported in Columns 1-4 of Table 1 and suggest that the number of polities crossed to get to Aleppo and Chang'an (i.e., political fragmentation in both directions) has consistently negative effects on city size. This is true after controlling for city and time fixed effects as well as the time-varying impacts of geography. Both variables are statistically significant when we control for the number of nonstate territories on the paths. From a substantive perspective, every additional polity crossed

\footnotetext{
${ }^{33}$ See Table S2 on page S-4 of the Appendix for summary statistics of all variables included in our regression analyses.
} 
to get to Aleppo is associated with a 12 to 14 percent decrease in city population, while for the polities crossed to get to Chang'an, a 5 to 9 percent decrease in city population, depending on the regression specification. We also find that while being a capital city consistently has a positive association with city size, being located in a non-state territory has the opposite effect on city population. ${ }^{34}$

Columns 5-8 of Table 1 present an alternative way to test the idea that political fragmentation reduced the gains from cross-regional trade. Rather than considering the number of politics crossed to either Aleppo or Chang'an, the economic prospects for a particular city may be a function of fragmentation on the entire East-West trade artery. In other words, the health of the entire route may matter for garnering trade-related gains and, as a result, fragmentation on the two segments should not be considered to be independent from one another. In this set of specifications the main explanatory variable of interest is the total number of polities crossed. We find that a larger number of polities crossed on the combined trade path is associated with lower city population. Every additional polity crossed along the route is associated with a 11 to 12 percent decrease in city population after controlling for capital city status and the number of non-state territories. In other words, the results we report are similar to those found in first four columns of Table 1.

Our empirical strategy rests on the assumption that deviations from the travel paths that we have identified (i.e., the combination of highland "nomadic corridors" and lowland "least-cost paths") are costly to merchants who view these paths as preferred travel routes. The topography of Central Asia - with large natural barriers like the Taklamakan and Gobi Deserts - make large deviations unlikely yet, nonetheless, we also validate our main findings

\footnotetext{
${ }^{34}$ Our goal here is not to make a causal argument regarding the effect of capital city status on city size. Although it is possible that capital status may have been determined by unforeseen factors, rather than endogenously driven by city size, we mainly include capital status to control for alternative channels associated with city size.
} 
using the travel paths identified in Hansen (2012) instead of the paths we have simulated. ${ }^{35}$ Using the routes identified by Hansen to generate our key independent variable - rather than our simulated Silk Road routes — we find the results to be similar to our main findings as reported in Table $1 .{ }^{36}$

Next, we include variables related to forms of hierarchy and hegemony within the Asian political sphere through an empirical investigation of the effects of the Chinese tributary system. Kang $(2010,591)$ writes that the East Asian tributary order was an "enduring, stable, and hierarchic system, with China clearly the hegemon" and a "viable and recognized international system with military, cultural, and economic dimensions that all intersected to create a...stable security system." In return for recognizing the legitimacy of Chinese preeminence in regional affairs, "China, as the economic, military, and cultural leader, was responsible for maintaining the political and security order in the region" (Wang 2013, 213). We test the impact of crossing Chinese tributary states, by including the number of polities on the paths classified as tributary states as additional control variables. We also include an indicator for whether the city is inside a tributary state or not.

Table 2 reports these results. While scholars have argued that tributary practice and exchanges may have facilitated trade in a number of ways (Hamashita 1994; Kim 2016), we find that crossing tributary states was also negatively associated with city size. With a full complement of control variables included, we find that crossing tributary states when heading to Aleppo to be more damaging than when heading to Chang'an; this suggests that the tribute system may have spurred less damaging effects for those travelling towards Chang'an and, thus, closer to China. The main results on polities crossed to Aleppo and Chang'an, respectively (Columns 1-4), as well as total polities crossed (Columns 5-8) show similar effects as reported in Table 1, suggesting that even after controlling for tributary state status the main effects persist.

\footnotetext{
${ }^{35}$ See Figure $\mathrm{S} 2$ on page $\mathrm{S}-11$ of the Appendix.

${ }^{36}$ See Table S3 on page S-5 of the Appendix for these results.
} 


\subsection{State Capacity and Political Stability as Additional Consid- erations}

One potential concern that could be raised about our existing analysis relates to omitted variable bias associated with differential levels of state capacity, in particular the relatively low levels of administrative capacity enjoyed by East, Central, and West Asian polities in the medieval and early modern periods. States during this historical era were vastly different entities than the ones that we observe today. As a result, how can we understand the ability of these historical states to have effectively governed their territories? Our operationalization of historical state capacity seeks to identify the extent to which there was an enduring state presence along each route in previous periods. Relative to a situation of historical "statelessness," state presence should be associated with greater stability and rule of law. Our time-based operationalization of state capacity seeks to capture the difference between the extent to which each natural travel path experienced state (versus non-state) rule in the previous century. We recognize, however, that this is not the only possible proxy measure for historical state capacity; as a result, we present our results with an alternative operationalization for state capacity in the paper's Appendix. ${ }^{37}$

In order to generate our time-based measure of state capacity, for the route connecting each city in our sample to Chang'an and Aleppo in our data we note which segments of the route intersected with polities one-hundred years earlier. Next, we divide the segment length by the total route length to derive a fraction for each city and year. This measure allows us to identify the proportion of the trade route from each city to Aleppo or Chang'an that

${ }^{37}$ In Section S3 on page S-7 of the Appendix we describe an alternative measure of state capacity based on a distance-decay model where our key assumption is that state capacity declines with distance from major cities. The results using the distance-based capacity measure in Table S5, page S-8 show consistent and similar findings to the ones presented here. 
experienced state presence one-hundred years earlier. The results presented in Columns 1 and 2 in Table 3 suggest that after controlling for this measure of historical state capacity, the number of polities crossed to Aleppo and Chang'an (as well as total polities crossed) remains negative and statistically significant.

In addition to being concerned with historical state capacity, one might also be interested in disentangling the impact of localized political stability from the number of polity crossings to Aleppo and Chang'an. Although our regression specifications include a number of fixed effects (city, time, and geographic features interacted with a time trend), we may also want to account for the way that political fragmentation impacted local conditions and associated city size. For example, localized instability has the potential to damage city growth as residents flee the area, but might also lead to increased city size if people in the periphery seek "safe harbor" behind city walls (e.g., Dincecco and Onorato 2016). These dynamics would be independent of trade and not captured by the fixed effects specification that we have proposed.

In order to take into account localized political conditions we measure the distance to the first polity crossing from each city toward Aleppo and Chang'an, respectively, and divide that value by the total route length. Larger distances, all else equal, suggests more localized political stability while smaller distances suggest a lower degree of local political control. We might also be interested in seeing if faraway political stability also matters for city size. Instability close to Silk Road endpoints might also damage city size as it may be very costly for long-distance traders to bring their goods to market; on the other hand, distant stability is measured as the distance to first polity crossing from Aleppo and Chang'an on the route to each city in the dataset, divided by route length. We are interested in seeing if our main variables of interest are robust, even after controlling for both these two forms of stability. ${ }^{38}$

\footnotetext{
${ }^{38}$ Figure S3 on page S-12 in the Appendix presents a stylized illustration of localized versus faraway polity crossings.
} 
These variables have a range of between 0 and 1 , where 0 means the city is located in a non-state territory and 1 means the entire trade route from city to destination is contained in the same polity. In Table 3 Columns 3 and 4, we include these proxy variables for local and faraway, or distant, conditions, in addition to our state capacity controls, for both separate and combined travel paths. We find that the negative relationship between polity-crossing and city size remains consistent. We also find that stable conditions around Chang'an positively impacted those cities connected by trade (Column 3), and that cities benefitted when the polities they belonged to exerted greater control over the combined local trade routes to Chang'an and Aleppo (Column 4). In other words, local stability may matter for city growth, at least in some specifications, but even after taking this variable into account, political fragmentation on natural travel paths continues to be negatively associated with city size.

\section{Conclusions}

While some of the most prominent works on historical development have focused on the origins of states and state institutions, scholars have increasingly drawn attention to the importance of transnational and global dynamics (Go and Lawson 2017, 8), including forms of pre-modern, proto-globalization. Cross-regional trade routes, like the Silk Roads, connected economic interests between prosperous regions of the world for centuries. ${ }^{39}$ In this paper, we take a long view with regard to the global economic order in the spirit of international relations scholars who are focused on longue durée trends in power and influence (e.g., Kupchan 2012; Acharya 2014).

Observers have long suggested that "the Silk Road was at its strongest when it was dominated by a few powerful dynasties," and that "political stability across wide areas

\footnotetext{
${ }^{39}$ Indeed, Spruyt (1998) has suggested that historical sociology might be used to advance systems theory within the field of international relations.
} 
enabled commerce to thrive." 40 Yet, empirical evidence for such conjectures has been largely unavailable. Our analysis represents an attempt to quantitatively interrogate the effects of fragmented political authority in pre-modern Asia. We find that the benefits of cross-cultural exchange are diminished as a result of shocks to political stability on trade routes. We find that intra-route fragmentation made trade difficult, suggesting the costs of jurisdictional uncertainty (Simmons 2005), formal and informal barriers to trade (Epstein 2000), and taxation on the common pool of merchants (Cox 2017). Recent interdisciplinary work in archeology and historical climate science has suggested that pre-modern state formation on the Central Asian steppe - a key location of Silk Road corridors — has been subject to exogenous weather-related shocks that impacted pastoral communities in ways that may not have been the case in other world regions. We extend recent scientific work that identifies likely Silk Road routes along naturally-occurring migration corridors that formed across the highlands of Asia. Political fragmentation along likely routes is associated with smaller city size, even after controlling for city and time fixed effects and the inclusion of a variety of control variables, including Chinese imperial tributary state status.

Our results draw attention to trade and exchange between Western and Eastern Asia, the most prosperous regions of the world before the rise of Western hegemony. Our focus on prosperity in pre-modern Asia does not tackle the question of why Europe pulled ahead of other world regions economically but does allow us to understand more about variation in development in a world of "natural states" rather than "open access orders" (North et al. 2012). Epstein $(2000,39)$ points out that while scholars have commonly viewed all pre-industrial economies as equally stagnant, "regional diversity has became the central question of recent research." This paper represents our scholarly contribution to answering this question and offers evidence that pre-modern forms of globalization flourished during historical periods characterized by large, land empires in Eurasia.

\footnotetext{
${ }^{40}$ Sophie Ibbotson, "On the Silk Road," Asian Geographic, May 242017.
} 


\section{References}

Abramson, Scott. 2017. "The Economic Origins of the Territorial State." International Organization. $71(1)$ : 97-130.

Abu-Lughod, Janet. 1989. Before European Hegemony: The World System A.D. 1250-1350. Oxford: Oxford University Press.

Acharya, Amitav. 2014. The End of American World Order. Boston, MA: Polity Press.

Allsen, Thomas. 2001. Culture and Conquest in Mongol Eurasia. New York, NY: Cambridge University Press.

Anderton, Charles and John Carter. 2001. "The Impact of War on Trade: An Interrupted Times-Series Study." Journal of Peace Research. 38(4): 445-457.

Attman, Arthur. 1991. "The Flow of Precious Metals Along the Trade Routes between Europe and Asia up to 1800." Asian Trade Routes. Editor, Karl Haellquist. London: Curzon Press.

Atwell, William. 1998. "Ming China and the Emerging World Economy." The Ming Dynasty, Part 2: 1368-1644. Editors, Denis Twitchett and Frederick Mote. Cambridge History of China.

Barendse, R.J. 2000. "Trade and State in the Arabian Seas: A Survey from the Fifteenth to the Eighteenth Century." Journal of World History. 11(2): 173-225.

Benite, Zvi. 2011. "Follow the White Camel: Islam in China to 1800." New Cambridge History of Islam. New York, NY: Cambridge University Press.

Blaydes, Lisa and Eric Chaney. 2013. "The Feudal Revolution and Europe's Rise: Political Divergence of the Christian West and the Muslim World Before 1500 CE." American Political Science Review. 107(1): 16-34. 
Blaydes, Lisa and Christopher Paik. 2016. "The Impact of Holy Land Crusades on State Formation: War Mobilization, Trade Integration and Political Development in Medieval Europe." International Organization. 70(3): 551-586.

Blaydes, Lisa and Christopher Paik. 2020. "Muslim Trade and City Growth before the 19th Century: Comparative Urbanization in Europe, the Middle East and Central Asia." British Journal of Political Science.

Blusse, Leonard, Jan Oosterhoff and Ton Vermeulen. 1991. "Chinese Trade with Batavia in the 17th and 18th Centuries: A Preliminary Report." Asian Trade Routes. Editor, Karl Haellquist. London: Curzon Press.

Boulding, Kenneth. 1962. Conflict and Defense: A General Theory. New York, NY: Harper $\&$ Bros.

Buntgen, Ulf and Nicola Di Cosmo. 2016. "Climatic and Environmental Aspects of the Mongol Withdrawal from Hungary in 1242 CE." Scientific Reports. 6.

Buzan, Barry and Richard Little. 1994. "The Idea of 'International System'." International Political Science Review. 15(3): 231-255.

Chaffee, John. 2015. "Reflections on the Sung." In Sung China, 960-1279 AD, Part 2. Editors, John W. Chaffee and Denis Twitchett. Cambridge History of China.

Chandler, Tertius and Gerald Fox. 1974. 3000 Year of Urban Growth. New York, NY: Academic Press.

Cinar, E. Mine, Katherine Geusz and Joseph Johnson. 2015. "Historical Perspectives on Trade and Risk on the Silk Road, Middle East and China." Topics in Middle Eastern and African Economies. 17(2).

Ciolek, T. Matthew. 1999-present. OWTRAD Notation System: a method for standardising and computerising geographical and logistical data about long-distance transportation/communication routes. Old World Trade Routes (OWTRAD) Project. Canberra: 
www.ciolek.com - Asia Pacific Research Online. Version 5.4 (Oct 2006). www.ciolek. com/OWTRAD/notation.html

Christian, David. 2000. "Silk Roads or Steppe Roads: The Silk Roads in World History." Journal of World History. 11(1): 1-26.

Clarence-Smith, William. 2011. "The Onset of Western Domination, 1800 to 1919." New Cambridge History of Islam. New York, NY: Cambridge University Press.

Cox, Gary. 2017. "Political Institutions, Economic Liberty, and the Great Divergence." Journal of Economic History. 77(3): 724-755

Curtin, Philip. 1984. Cross-cultural Trade in World History. New York, NY: Cambridge University Press.

De Long, Bradford and Andrei Shleifer. 1993. "Princes and Merchants: European City Growth before the Industrial Revolution." Journal of Law and Economics. 36(2): 671702.

Dincecco, Mark. 2010. "Fragmented Authority from Ancien Regime to Modernity: A Quantitative Analysis." Journal of Institutional Economics. 6(3): 305-328.

Dincecco, Mark and Massimiliano Onorato. 2016. From Warfare to Wealth: The Military Origins of Urban Prosperity in Europe. New York, NY: Cambridge University Press.

Dincecco, Mark and Yuhua Wang. 2018. "Violent Conflict and Political Development Over the Long Run: China Versus Europe." Annual Review of Political Science. 21: 341-358.

Enkhbold, Enerelt. 2019. "The Role of the Ortoq in the Mongol Empire in Forming Business Partnerships." Central Asian Survey. 38(4): 531-547.

Epstein, S.R. 2000. Freedom and Growth: The Rise of States and Markets in Europe, 13001750. London: Routledge. 
Frachetti, Michael, C. Evan Smith, Cynthia M. Traub amd Tim Williams. 2017. "Nomadic Ecology Shaped the Highland Geography of Asia's Silk Roads." Nature. 543(7644): 193-198.

Frank, Andre Gunder. 1992. "The Centrality of Central Asia." Studies in History. 8(1).

Frank, Andre Gunder. 1998. ReORIENT: Global Economy in the Asian Age. Berkeley, CA: University of California Press.

Frankopan, Peter. 2016. The Silk Roads: A New History of the World. New York, NY: Alfred Knopf.

Gilbar, Gad. 2003. "The Muslim Big Merchant-Entrepreneurs of the Middle East, 18601914." Die Welt des Islams. 43(1): 1-36.

Glick, Reuven and Alan Taylor. 2010. "Collateral Damage: Trade Disruption and the Economic Impact of War." Review of Economics and Statistics. 92(1): 102-127.

Go, Julian and George Lawson. 2017. "For a Global Historical Sociology." Global Historical Sociology. Editors, Julian Go and George Lawson. New York, NY: Cambridge University Press.

Goiten, S.D. 1967. A Mediterranean Society: The Jewish Communities of the Arab World as Portrayed in the Documents of the Cairo Geniza. Berkeley, CA: University of California Press.

Hansen, Valerie. 2012. The Silk Road: A New History. New York, NY: Oxford University Press.

Harris, Lillian. 1993. China Considers the Middle East. London: I.B. Tauris.

Hofstede, G. and G.J. Hofstede and M. Minkov. 2010. Cultures and Organizations: Software of the Mind: Intercultural Cooperation and Its Importance for Survival (Third Edition). New York: McGraw Hill. 
Honeychurch, William. 2014. Inner Asia and the Spatial Politics of Empire: Archaeology, Mobility, and Culture Contact. New York, NY: Springer.

Inalcik, Halil. 1994. An Economic and Social History of the Ottoman Empire, Volume 1. New York, NY: Cambridge University Press.

Jervis, Robert. 1997. System Effects: Complexity in Political and Social Life. Princeton, NJ: Princeton University Press.

Jones, Eric. 2003. The European Miracle: Environments, Economies and Geopolitics in the History of Europe and Asia. New York, NY: Cambridge University Press.

Kang, David. 2010. "Hierarchy and Legitimacy in International Systems: The Tribute System in Early Modern East Asia." Security Studies. 19:4, 591-622.

Kang, David. 2010. East Asia Before the West: Five Centuries of Trade and Tribute. New York, NY: Columbia University Press.

Kang, David. 2013. "International Relations Theory and East Asian History: An Overview." Journal of East Asian Studies. 13: 181-205.

Kim, Kwangmin. 2016. Borderland Capitalism: Turkestan Produce, Qing Silver, and the Birth of an Eastern Market. Palo Alto, CA: Stanford University Press.

Krasner, Stephen. 1976. "State Power and the Structure of International Trade." World Politics. 28(3): 317-347.

Kupchan, Charles. 2012. No One's World: The West, the Rising Rest, and the Coming Global Turn. New York, NY: Oxford University Press.

Lary, Diana. 2012. Chinese Migrations: The Movement of People, Goods, and Ideas over Four Millennia. New York, NY: Rowman \& Littlefield Publishers.

Lee, Ji-Young. 2016. China's Hegemony: Four Hundred Years of East Asian Domination. New York, NY: Columbia University Press. 
Levi, Scott. 2011. "Commercial Structures." New Cambridge History of Islam. New York, NY: Cambridge University Press.

Lind, Jennifer. 2018. "Life in China's Asia: What Regional Hegemony Would Look Like." Foreign Affairs. March/April.

Liu, William Guanglin. 2015. The Chinese Market Economy, 1000-1500. Albany, NY: State University of New York Press.

Lombard, Maurice. 1975. The Golden Age of Islam. New York, NY: Elsevier.

Manz, Beatrice. 2011. "The Rule of the Infidels: The Mongols and the Islamic World." New Cambridge History of Islam. New York, NY: Cambridge University Press.

Matthee, Rudi. 1994. "Anti-Ottoman Politics and Transit Rights: The Seventeenth-Century Trade in Silk between Safavid Iran and Muscovy." Cahiers du Monde Russe. 35(4): 739761.

Meloy, John. 2011. "Overland Trade in the Western Islamic World." New Cambridge History of Islam. New York, NY: Cambridge University Press.

Millward, James. 2007. Eurasian Crossroads: A History of Xinjiang. New York, NY: Columbia University Press.

North, Douglass, John Joseph Wallis and Barry Weingast. 2012. Violence and Social Orders: A Conceptual Framework for Interpreting Recorded Human History. New York, NY: Cambridge University Press.

Park, Hyunhee. 2012. Mapping the Chinese and the Islamic Worlds: Cross-Cultural Exchange in Pre-Modern Asia. New York, NY: Cambridge University Press.

Park, Seo-Hyun. 2017. Sovereignty and Status in East Asian International Relations. New York, NY: Cambridge University Press. 
Perdue, Peter. 2015. "The Tenacious Tributary System." Journal of Contemporary China. 24(96): 1002-1014.

Phillips, Andrew and Jason Sharman. 2015. International Order in Diversity: War, Trade and Rule in the Indian Ocean. New York, NY: Cambridge University Press.

Ranjbar, Mohammed Ali and Sehhat Manesh, Reza. 2016. "New Routes to Iran's International Trade in the Safavid Era." Ancient Asia. 7.

Rogers, J. Daniel. 2007. "The Contingencies of State Formation in Eastern Inner Asia." Asian Perspectives. 46(2): 249-274.

Rogers, J. Daniel. 2012. "Inner Asian States and Empires: Theories and Synthesis." Journal of Archaeological Research. 20: 205-256.

Rosenthal, Jean-Laurent and Roy Bin Wong. 2011. Before and Beyond Divergence: The Politics of Economic Change in China and Europe. Cambridge, MA: Harvard University Press.

Schafer, Edward. 1963. The Golden Peaches of Samarkand: A Study of Tang Exotics. Berkeley, CA: University of California Press.

Shleifer, Andrei and Robert Vishny. 1993. "Corruption." Quarterly Journal of Economics. 108(3): 599-617.

Schottenhammer, Angela. 2015. "China's Emergence as a Maritime Power." In Sung China, 960-1279 AD, Part 2. Editors, John W. Chaffee and Denis Twitchett. Cambridge History of China.

Sharman, Jason. 2019. Empires of the Weak: The Real Story of European Expansion and the Creation of the New World Order. Princeton, NJ: Princeton University Press.

Shu, Min. 2012. "Hegemon and Instability: Pre-Colonial Southeast Asia under the Tribute System." Waseda Institute for Advanced Study Research Bulletin. 4: 45-62. 
Simmons, Beth. 2005. "Rules over Real Estate: Trade, Territorial Conflict and International Borders as Institution." Journal of Conflict Resolution. 49(6): 823-848.

Soucek, Svat. 2000. A History of Inner Asia. New York, NY: Cambridge University Press.

Spruyt, Hendrik. 1994. The Sovereign State and its Competitors. Princeton, NJ: Princeton University Press.

Spruyt, Hendrik. 1998. "Historical Sociology and Systems Theory in International Relations." Review of International Political Economy. 5(2): 340-353.

Stasavage, David. 2014. "Was Weber Right? The Role of Urban Autonomy in Europe's Rise." American Political Science Review. 108(2): 337-354.

Steensgaard, Niels. 1973. The Asian Trade Revolution of the Seventeenth-century: The East India Companies and the Decline of the Caravan Trade. Chicago, IL: University of Chicago Press.

von Glahn, Richard. 2016. The Economic History of China: From Antiquity to the Nineteenth Century. New York, NY: Cambridge University Press.

Weatherford, Jack. 2004. Genghis Khan and the Making of the Modern World. New York, NY: Crown.

Wong, R. Bin. 1997. China Transformed: Historical Change and the Limits of European Experience. Ithaca, NY: Cornell University Press.

Van Lieu, Joshua. 2017. "The Tributary System and the Persistence of Late Victorian Knowledge." Harvard Journal of Asiatic Studies. 77(1): 73-92.

Yuan-kang, Wang. 2012. "Managing Regional Hegemony in Historical Asia: The Case of Early Ming China." Chinese Journal of International Politics. 5: 129-153.

Zhang, Yongjin. 2013. "The Tribute System." Oxford Bibliographies. 


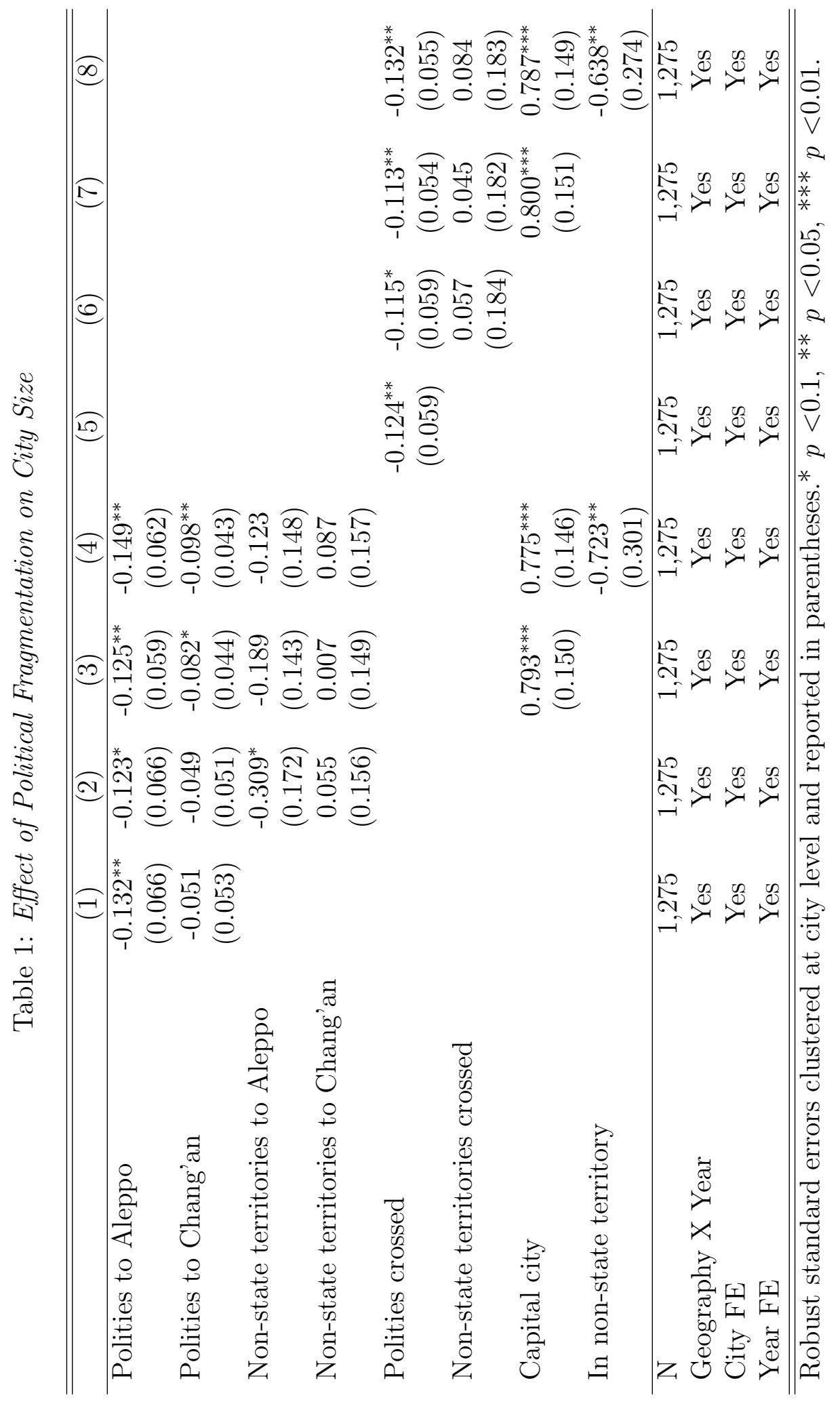




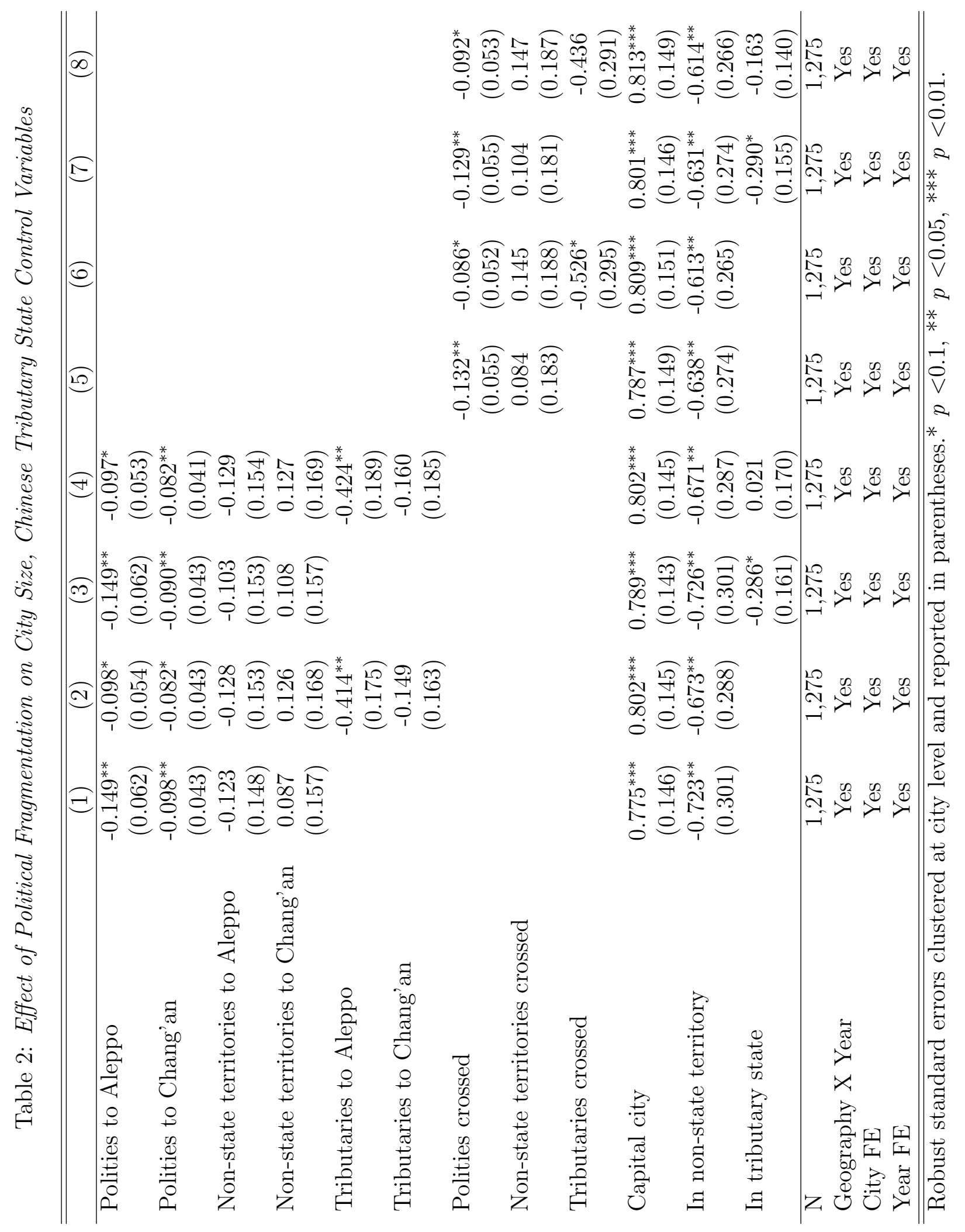


Table 3: Effect of Political Fragmentation on City Size, State Capacity and Political Stability Control Variables

\begin{tabular}{|c|c|c|c|c|}
\hline & $(1)$ & $(2)$ & $(3)$ & (4) \\
\hline Polities to Aleppo & $\begin{array}{c}-0.200^{* * *} \\
(0.065)\end{array}$ & & $\begin{array}{c}-0.220^{* * *} \\
(0.078)\end{array}$ & \\
\hline Polities to Chang'an & $\begin{array}{c}-0.153^{* *} \\
(0.065)\end{array}$ & & $\begin{array}{l}-0.083 \\
(0.063)\end{array}$ & \\
\hline Non-state territories to Aleppo & $\begin{array}{l}-0.073 \\
(0.182)\end{array}$ & & $\begin{array}{l}-0.079 \\
(0.191)\end{array}$ & \\
\hline Non-state territories to Chang'an & $\begin{array}{c}0.056 \\
(0.173)\end{array}$ & & $\begin{array}{c}0.096 \\
(0.171)\end{array}$ & \\
\hline Polities crossed & & $\begin{array}{c}-0.232^{* * *} \\
(0.059)\end{array}$ & & $\begin{array}{c}-0.135^{* *} \\
(0.059)\end{array}$ \\
\hline Non-state territories crossed & & $\begin{array}{c}0.096 \\
(0.198)\end{array}$ & & $\begin{array}{c}0.079 \\
(0.192)\end{array}$ \\
\hline Historical state capacity to Aleppo & $\begin{array}{l}2.892^{* *} \\
(1.265)\end{array}$ & & $\begin{array}{l}3.058^{* *} \\
(1.388)\end{array}$ & \\
\hline Historical state capacity to Chang'an & $\begin{array}{c}0.100 \\
(0.844)\end{array}$ & & $\begin{array}{c}0.026 \\
(0.796)\end{array}$ & \\
\hline Historical state capacity (total polities crossed) & & $\begin{array}{c}1.566 \\
(2.303)\end{array}$ & & $\begin{array}{c}0.818 \\
(2.109)\end{array}$ \\
\hline Local stability to Aleppo & & & $\begin{array}{l}-0.024 \\
(0.266)\end{array}$ & \\
\hline Local stability to Chang'an & & & $\begin{array}{c}0.251 \\
(0.404)\end{array}$ & \\
\hline Distant stability from Aleppo & & & $\begin{array}{l}-0.672 \\
(0.693)\end{array}$ & \\
\hline Distant stability from Chang'an & & & $\begin{array}{c}0.801^{*} \\
(0.478)\end{array}$ & \\
\hline Local stability (to Aleppo/Chang'an) & & & & $\begin{array}{c}0.957^{*} \\
(0.523)\end{array}$ \\
\hline Distant stability (from Aleppo/Chang'an) & & & & $\begin{array}{c}1.278 \\
(1.397) \\
\end{array}$ \\
\hline $\mathrm{N}$ & 1,105 & 1,105 & 1,105 & 1,105 \\
\hline Geography X Year & Yes & Yes & Yes & Yes \\
\hline City FE & Yes & Yes & Yes & Yes \\
\hline Year FE & Yes & Yes & Yes & Yes \\
\hline Capital city & Yes & Yes & Yes & Yes \\
\hline In non-state territory & Yes & Yes & Yes & Yes \\
\hline
\end{tabular}

Robust standard errors clustered at city level and reported in parentheses.

$* p<0.1,{ }^{* *} p<0.05,{ }^{* * *} p<0.01$. 

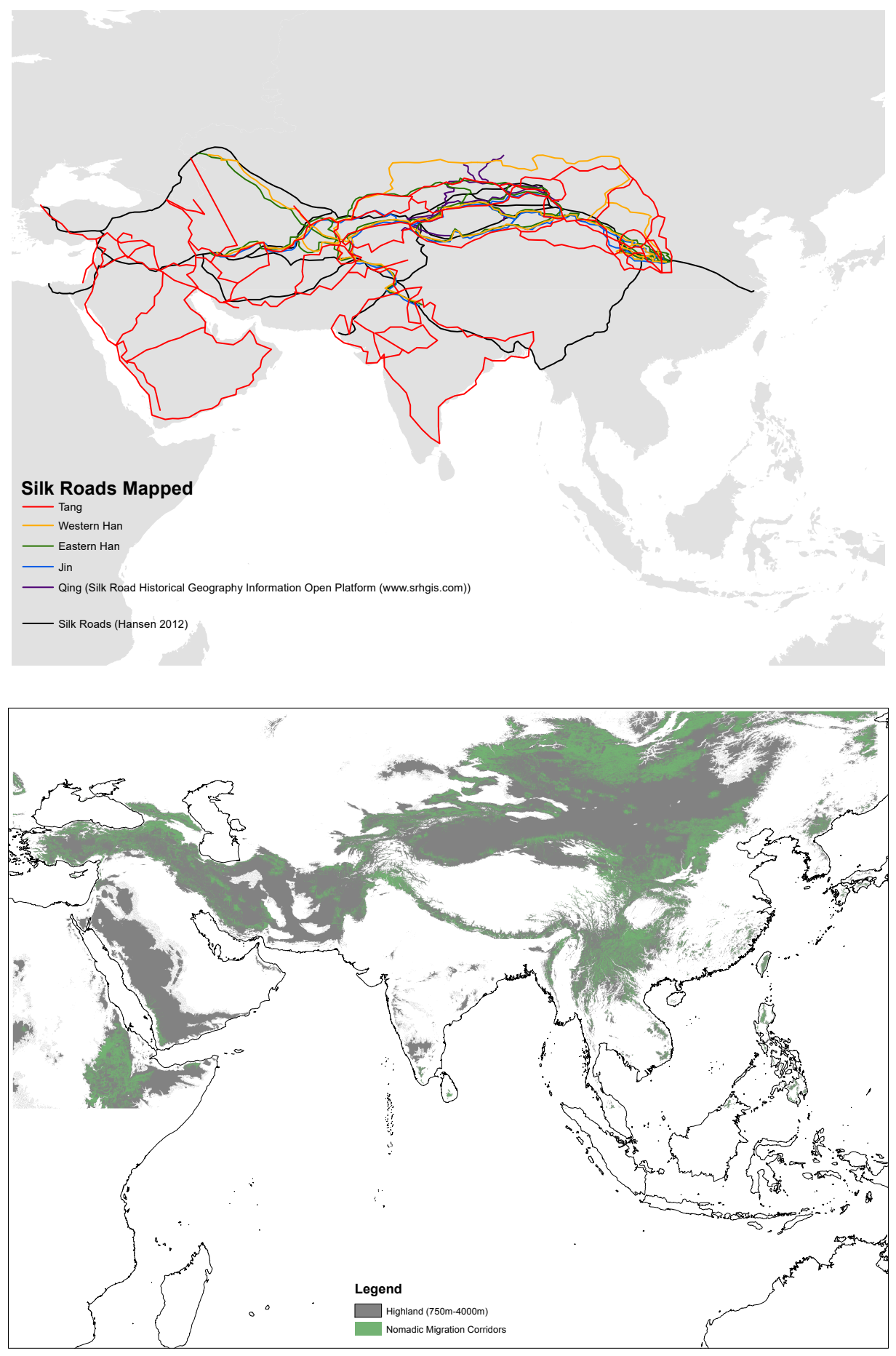

Figure 1: Silk Roads Mapped (Top); Highlands and Nomadic Corridors (Bottom) 


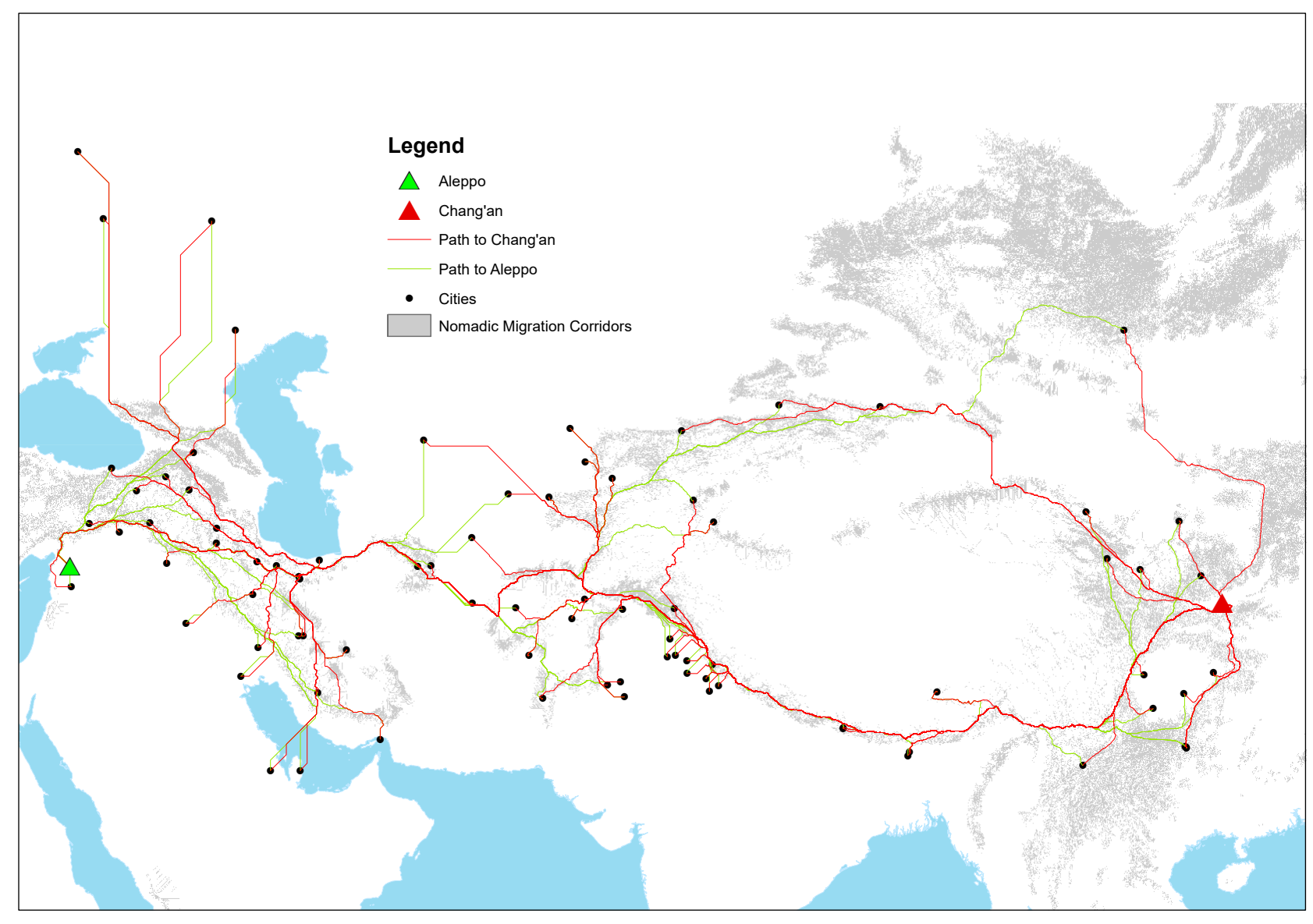

Figure 2: Natural Travel Paths as a Proxy for Silk Roads 


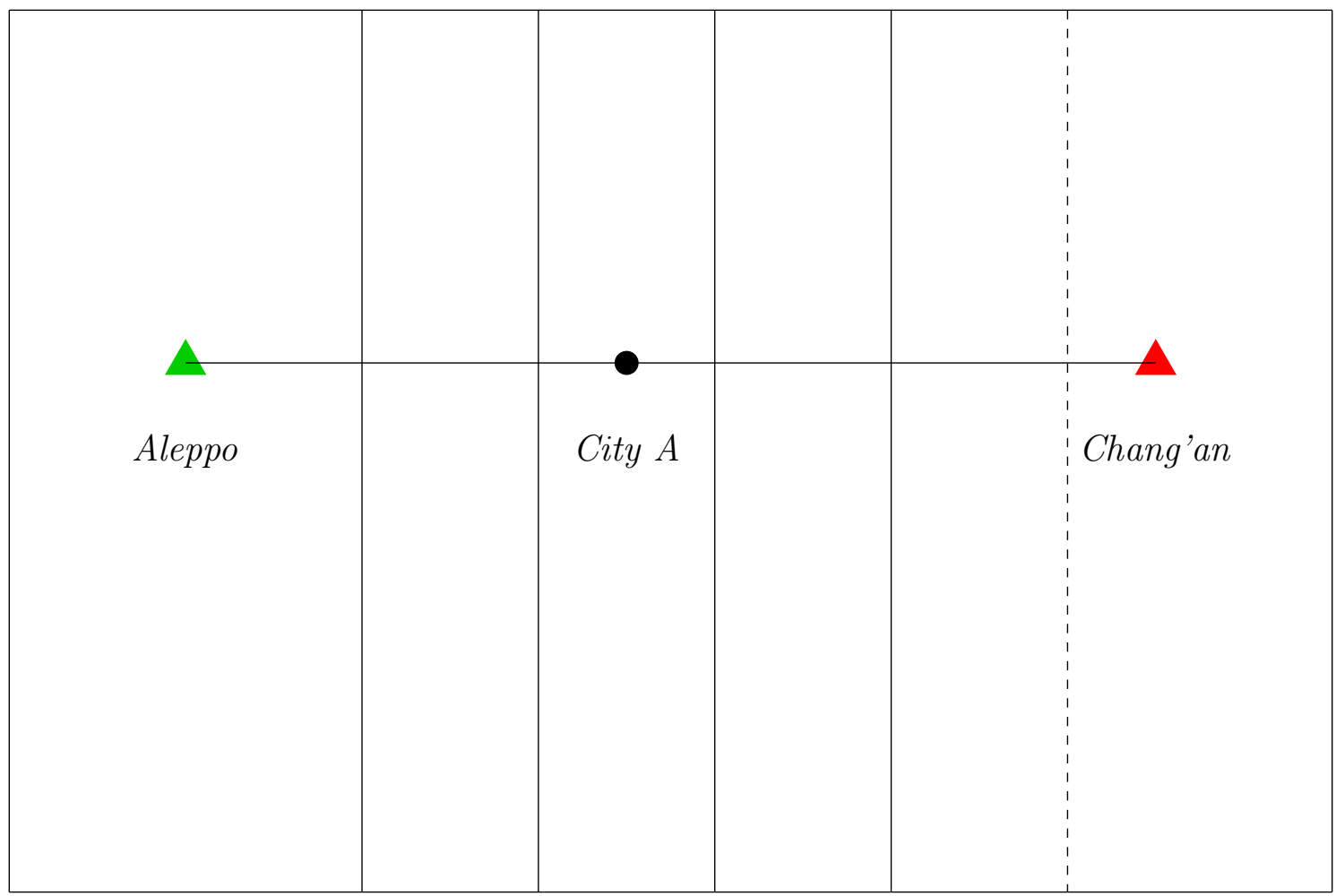

Figure 3: Stylized illustration of the argument regarding the effects of crossing jurisdictions on the costs of trade. The solid lines represent divisions between independent polities. The dotted lines represent independent polities that fall under the Chinese imperial tribute system. 


\begin{abstract}
Appendix
"Trade and Political Fragmentation on the Silk Roads: The Economic Effects of Historical Exchange between China and the Muslim East"
\end{abstract}

December 2019 


\section{Contents}

$\begin{array}{lr}\text { S1 Description of City Population and Interval Regression } & \text { S-2 }\end{array}$

$\begin{array}{lr}\text { S2 Tables } & \text { S-2 }\end{array}$

$\begin{array}{lr}\text { S3 Alternative measure of state capacity } & \text { S-3 }\end{array}$

$\begin{array}{lr}\text { S4 Figures } & \text { S-9 }\end{array}$ 


\section{S1 Description of City Population and Interval Regression}

The city population come from Chandler and Fox (1974), who provide population data for cities around the world as early as $1360 \mathrm{BCE}$ to $1968 \mathrm{CE}$. We utilize population estimates from 1100 to 1800 , for which the authors provide lists of the largest cities of the world for every 50 years. Our data contain all the cities which appear at least once in any of the lists for the world's largest cities across the time periods. While actual population figures are often missing for cities on these lists, Chandler and Fox (1974) do provide rankings of cities in the order of their size. For these missing entries we follow the convention that city size can be approximated by the power law (Rozenfeld et al. 2011; Eeckhout 2004; Gabaix 2009) and follow the interpolation approach as described in detail in Blaydes and Paik (forthcoming). That is, the OLS estimate of the log of population for each missing city on the list is assumed a linear function of the $\log$ of its known rank and a constant:

$$
\text { LogPopulation }_{i}=\alpha+\beta_{1} \log \operatorname{Rank}_{i}+\varepsilon_{i}
$$

Using the slope estimate for each year and the rank from the lists, we can calculate the population estimate for each missing city-period observation. In Blaydes and Paik (forthcoming), the authors focus their analysis primarily on the impact of Muslim trade routes and limit their scope of analysis to cities from North Africa to Central Asia. In this paper, we extend the sample of cities to sub-Saharan Africa and East Asia and look at the global changes in trade patterns and subsequent urbanization trends. For the cases where a city is missing from the top list in one period but not others (and thus still included in our data), we create an interval of a lower bound and an upper bound for its population. We assign zero as the lower bound for the city population for the period, and the population of the smallest city that appears on the period's list as the upper bound for the missing city population. In other words, the population of a city missing from the top list in a given period but on the list on another period takes a range of values between zero and the lowest estimate from the top list for that period. Finally, we utilize additional population data records from Chandler and Fox (1974) to replace any intervals with actual population figures, if and when available.

Using the data estimation approach as described above, we obtain population interval data for 209 cities across Central and East Asia for every 50 years from 1100 to 1800, drawing from the ranked list of largest cities provided by the authors over this time period. From this data, we confine cities in our sample to those west of Chang'an and east of Aleppo. We also restrict our sample to those located above the 25-degree latitude. The resulting set of cities, 85 of them in total, allows us to focus on the region of our primary interest: cities in the steppes of Central Asia where political stability was arguably more random and exogenously determined than others. Cities below the 25-degree latitude include cities in the Indian subcontinent as well as Southeast Asia, in which maritime trade routes along the coast would have been much more common and practical than overland trade routes. These cities as trading posts were fundamentally different from the cities that we mainly focus on.

In our main analysis we use a generalized maximum log likelihood interval model to obtain the coefficient estimates. ${ }^{1}$ When the error term $\varepsilon$ is normally and identically distributed, the log likelihood can be expressed as:

$$
\ln L=-\frac{1}{2} \sum_{j \in P}\left\{\left(\frac{y_{j}-x \beta}{\sigma}\right)^{2}+\log 2 \pi \sigma^{2}\right\}+\sum_{k \in I} \log \left\{\Phi\left(\frac{y_{2 k}-x \beta}{\sigma}\right)-\Phi\left(\frac{y_{1 k}-x \beta}{\sigma}\right)\right\}
$$

where $j \in P$ refers to observation $j$ in point data, and $k \epsilon I$ refers to observation $k$ in interval data, in which the unobserved $y_{k}$ is in the interval $\left[y_{1 k}, y_{2 k}\right]$. The coefficient $\beta_{3}$ captures the effects of our explanatory variables.

\section{S2 Tables}

\footnotetext{
${ }^{1}$ We use the stata command intreg2, which takes interval data including point as well as right and left-censored.
} 
Table S1: Eurasian Urban Center of Gravity, 1100-1800 CE

\begin{tabular}{cccc} 
Year & Latitude & Longitude & Count \\
\hline \hline 1100 & 32.99631 & 61.98586 & 586 \\
1150 & 33.15095 & 59.91880 & 586 \\
1200 & 32.94798 & 59.67324 & 586 \\
1250 & 33.05159 & 60.11353 & 586 \\
1300 & 33.23095 & 60.82225 & 586 \\
1350 & 33.15543 & 61.44813 & 586 \\
1400 & 33.13059 & 61.44409 & 586 \\
1450 & 32.98265 & 62.26588 & 586 \\
1500 & 32.97121 & 62.28126 & 586 \\
1550 & 33.58465 & 59.81576 & 586 \\
1600 & 33.57519 & 62.21168 & 586 \\
1650 & 33.74231 & 61.06998 & 586 \\
1700 & 33.85598 & 62.18932 & 586 \\
1750 & 34.46906 & 61.89826 & 586 \\
1800 & 35.05676 & 62.71095 & 586 \\
\hline \hline
\end{tabular}

\section{S3 Alternative measure of state capacity}

As an alternative to our time-based state capacity measure, we introduce a measure of state capacity based on a distance-decay model where our key assumption is that state capacity declines with distance from major cities. Throughout much of history, state capacity depended heavily on political authority emanating from nearby cities given the role of urban areas as locations of political and economic power. Merchants traveling on trade routes benefitted from protection and amenities provided by cities, benefits that may have declined as one traveled farther from urban centers. For example, frontier areas - like the Syrian desert between the Ottoman Empire and Persia or mountainous areas between Persia and Indian polities - were difficult to bring under state control (Steensgaard 1973, 61).

We can calculate a state capacity proxy variable that takes into account two factors - distance to cities and city size - for each trade route. ${ }^{2}$ For example, in order to calculate the capacity measure for city $i$ based on its route to Aleppo, we obtain the nearest geodesic distance between every city $j \neq i$ in our data and city $i$ 's route to Aleppo. Next, we divide city $j$ 's population by this distance to get the weighted population for the city. Finally, we sum all the weighted city $j \neq i$ populations to get the distance-based capacity measure for city $i$ in year $t$. That is, the capacity measure for city $i$, with its trade route extending from the city to Aleppo or Chang'an in time $t$, can be calculated as the total population estimate of all the cities in our data sample, weighted by their distances to the route, and written as follows:

$$
\text { Capacity }_{i t}=\sum_{j \neq i}^{n} \frac{\text { pop }_{j t}}{\text { dist }_{i j}}
$$

where subscript $\operatorname{pop}_{j t}$ is the mean population estimate of city $j$ at time $t$, and dist $t_{i j}$ is the nearest geodesic distance between the route connecting city $i$ to Aleppo or Chang'an, and city $j$. The following results in Table S5

\footnotetext{
${ }^{2}$ This familiar distance-based argument is similar in spirit to Boulding (1962)'s distance-decay mechanism that seeks to explain a state's potential reach.
} 
Table S2: Summary Statistics

Mean population (in 1000s)

Polities to Aleppo

Polities to Chang' an

Polities crossed

Tributaries to Aleppo

Tributaries to Chang' an

Tributaries crossed

Non-state territories to Aleppo

Non-state territories to Chang' an

Non-state territories crossed

Capital city

In tributary state

In non-state territory

In non-state territory

Distance to nearest natural path $(\mathrm{km})$

Distance to coast $(\mathrm{km})$

Longitude

Latitude

Mean elevation (m)

STD elevation $(\mathrm{m})$

State capacity to Aleppo, $t-50$

State capacity to Aleppo, $t-100$

State capacity to Chang'an, $t-50$

State capacity to Chang' an, $t-100$

State capacity along total path, $t-50$

State capacity along total path, $t-100$

Distance-based capacity (path to Aleppo)

Distance-based capacity (path to Chang'an)

Distance-based capacity (combined path)

Local stability (path to Aleppo)

Local stability (path to Chang'an)

Distant stability (path from Aleppo)

Distant stability (path from Chang'an)

Local stability (combined path)

Distant stability (paths from Aleppo/Chang'an)

Observations

$\begin{array}{ccccc}\text { mean } & \text { sd } & \text { min } & \text { max } & \text { count } \\ 36.11 & 33.37 & 3 & 600 & 1,275 \\ 5.03 & 2.92 & 1 & 16 & 1,275 \\ 5.48 & 2.80 & 1 & 17 & 1,275 \\ 9.25 & 2.74 & 2 & 20 & 1,275 \\ 0.49 & 0.77 & 0 & 3 & 1,275 \\ 0.76 & 0.95 & 0 & 3 & 1,275 \\ 1.05 & 1.05 & 0 & 4 & 1,275 \\ 0.53 & 0.82 & 0 & 3 & 1,275 \\ 1.62 & 1.02 & 0 & 4 & 1,275 \\ 1.98 & 0.80 & 0 & 4 & 1,275 \\ 0.05 & 0.23 & 0 & 1 & 1,275 \\ 0.15 & 0.36 & 0 & 1 & 1,275 \\ 0.04 & 0.19 & 0 & 1 & 1,275 \\ 0.04 & 0.19 & 0 & 1 & 1,275 \\ 116.46 & 279.41 & 0 & 1,678 & 1,275 \\ 993.30 & 651.34 & 1 & 2,934 & 1,275 \\ 68.40 & 21.28 & 37 & 108 & 1,275 \\ 35.05 & 6.20 & 25 & 54 & 1,275 \\ 1,035.66 & 864.81 & -10 & 4,367 & 1,275 \\ 241.26 & 221.58 & 5 & 1,058 & 1,275 \\ 0.95 & 0.08 & 0 & 1 & 1,190 \\ 0.95 & 0.09 & 0 & 1 & 1,105 \\ 0.79 & 0.13 & 0 & 1 & 1,190 \\ 0.78 & 0.13 & 0 & 1 & 1,105 \\ 0.84 & 0.05 & 1 & 1 & 1,190 \\ 0.83 & 0.05 & 1 & 1 & 1,105 \\ 99.99 & 364.53 & 0 & 7,211 & 1,275 \\ 39.14 & 81.38 & 0 & 1,162 & 1,275 \\ 133.76 & 435.79 & 0 & 8,358 & 1,275 \\ 0.30 & 0.30 & 0 & 1 & 1,275 \\ 0.27 & 0.32 & 0 & 1 & 1,275 \\ 0.25 & 0.26 & 0 & 1 & 1,275 \\ 0.36 & 0.28 & 0 & 1 & 1,275 \\ 0.19 & 0.15 & 0 & 1 & 1,275 \\ 0.22 & 0.08 & 0 & 1 & 1,275 \\ 1275 & & & & \end{array}$


Table S3: Effect of Political Fragmentation on City Size (Hansen)

\begin{tabular}{|c|c|c|c|c|c|c|c|c|}
\hline & separate & & & & combined & & & \\
\hline Polities to Aleppo & $\begin{array}{l}-0.069 \\
(0.060)\end{array}$ & $\begin{array}{l}-0.065 \\
(0.055)\end{array}$ & $\begin{array}{c}-0.092^{*} \\
(0.048)\end{array}$ & $\begin{array}{c}-0.100^{* *} \\
(0.049)\end{array}$ & & & & \\
\hline Polities to Chang'an & $\begin{array}{l}-0.069 \\
(0.067)\end{array}$ & $\begin{array}{l}-0.096 \\
(0.073)\end{array}$ & $\begin{array}{c}-0.119^{*} \\
(0.070)\end{array}$ & $\begin{array}{c}-0.126^{*} \\
(0.070)\end{array}$ & & & & \\
\hline Non-state territories to Aleppo & & $\begin{array}{c}-0.741^{* * *} \\
(0.278)\end{array}$ & $\begin{array}{c}-0.609^{* *} \\
(0.264)\end{array}$ & $\begin{array}{c}-0.536^{*} \\
(0.280)\end{array}$ & & & & \\
\hline Non-state territories to Chang'an & & $\begin{array}{c}0.220 \\
(0.154)\end{array}$ & $\begin{array}{c}0.106 \\
(0.150)\end{array}$ & $\begin{array}{c}0.126 \\
(0.153)\end{array}$ & & & & \\
\hline Polities crossed & & & & & $\begin{array}{c}-0.079 \\
(0.058)\end{array}$ & $\begin{array}{c}-0.078 \\
(0.057)\end{array}$ & $\begin{array}{c}-0.108^{* *} \\
(0.049)\end{array}$ & $\begin{array}{c}-0.111^{* *} \\
(0.049)\end{array}$ \\
\hline Non-state territories crossed & & & & & & $\begin{array}{c}0.040 \\
(0.146)\end{array}$ & $\begin{array}{l}-0.010 \\
(0.147)\end{array}$ & $\begin{array}{c}-0.006 \\
(0.145)\end{array}$ \\
\hline Capital city & & & $\begin{array}{c}0.803^{* * *} \\
(0.141)\end{array}$ & $\begin{array}{c}0.792^{* * *} \\
(0.141)\end{array}$ & & & $\begin{array}{c}0.831^{* * *} \\
(0.146)\end{array}$ & $\begin{array}{c}0.821^{* * *} \\
(0.144)\end{array}$ \\
\hline In non-state territory & & & & $\begin{array}{c}-0.522^{*} \\
(0.293)\end{array}$ & & & & $\begin{array}{c}-0.520^{*} \\
(0.276)\end{array}$ \\
\hline $\mathrm{N}$ & 1,275 & 1,275 & 1,275 & 1,275 & 1,275 & 1,275 & 1,275 & 1,275 \\
\hline Geography X Year & Yes & Yes & Yes & Yes & Yes & Yes & Yes & Yes \\
\hline City FE & Yes & Yes & Yes & Yes & Yes & Yes & Yes & Yes \\
\hline Year FE & Yes & Yes & Yes & Yes & Yes & Yes & Yes & Yes \\
\hline
\end{tabular}

Robust standard errors clustered at city level and reported in parentheses.* $p<0.1,{ }^{* *} p<0.05, * * * p<0.01$. 
Table S4: Effect of Political Fragmentation on City Size, Capacity Control Variables

\begin{tabular}{|c|c|c|c|c|}
\hline & $\mathrm{t}-100$ & $\mathrm{t}-50$ & $\mathrm{t}-100($ combined $)$ & $\mathrm{t}-50$ (combined) \\
\hline Polities to Aleppo & $\begin{array}{c}-0.200^{* * *} \\
(0.065)\end{array}$ & $\begin{array}{c}-0.208^{* * *} \\
(0.065)\end{array}$ & & \\
\hline Polities to Chang'an & $\begin{array}{c}-0.153^{* *} \\
(0.065)\end{array}$ & $\begin{array}{c}-0.153^{* *} \\
(0.064)\end{array}$ & & \\
\hline Non-state territories to Aleppo & $\begin{array}{l}-0.073 \\
(0.182)\end{array}$ & $\begin{array}{l}-0.061 \\
(0.185)\end{array}$ & & \\
\hline Non-state territories to Chang'an & $\begin{array}{c}0.056 \\
(0.173)\end{array}$ & $\begin{array}{c}0.077 \\
(0.165)\end{array}$ & & \\
\hline Polities crossed & & & $\begin{array}{c}-0.232^{* * *} \\
(0.059)\end{array}$ & $\begin{array}{c}-0.234^{* * *} \\
(0.061)\end{array}$ \\
\hline Non-state territories crossed & & & $\begin{array}{c}0.096 \\
(0.198)\end{array}$ & $\begin{array}{c}0.094 \\
(0.199)\end{array}$ \\
\hline Capital city & $\begin{array}{c}0.780^{* * *} \\
(0.170)\end{array}$ & $\begin{array}{c}0.782^{* * *} \\
(0.170)\end{array}$ & $\begin{array}{c}0.772^{* * *} \\
(0.172)\end{array}$ & $\begin{array}{c}0.773^{* * *} \\
(0.173)\end{array}$ \\
\hline In non-state territory & $\begin{array}{c}-0.893^{* * *} \\
(0.319)\end{array}$ & $\begin{array}{c}-0.878^{* * *} \\
(0.304)\end{array}$ & $\begin{array}{c}-0.876^{* * *} \\
(0.254)\end{array}$ & $\begin{array}{c}-0.870^{* * *} \\
(0.249)\end{array}$ \\
\hline State capacity to Aleppo, $t-100$ & $\begin{array}{l}2.892^{* *} \\
(1.265)\end{array}$ & $\begin{array}{l}1.920^{*} \\
(1.114)\end{array}$ & & \\
\hline State capacity to Chang'an, $t-100$ & $\begin{array}{c}0.100 \\
(0.844)\end{array}$ & $\begin{array}{c}0.756 \\
(0.879)\end{array}$ & & \\
\hline State capacity to Aleppo, $t-50$ & & $\begin{array}{l}2.597^{*} \\
(1.495)\end{array}$ & & \\
\hline State capacity to Chang' an, $t-50$ & & $\begin{array}{c}-0.848 \\
(1.028)\end{array}$ & & \\
\hline State capacity combined path, $t-100$ & & & $\begin{array}{c}1.566 \\
(2.303)\end{array}$ & $\begin{array}{l}1.199 \\
(2.455)\end{array}$ \\
\hline State capacity combined path, $t-50$ & & & & $\begin{array}{c}0.652 \\
(2.492) \\
\end{array}$ \\
\hline $\mathrm{N}$ & 1,105 & 1,105 & 1,105 & 1,105 \\
\hline Geography X Year & Yes & Yes & Yes & Yes \\
\hline City FE & Yes & Yes & Yes & Yes \\
\hline Year FE & Yes & Yes & Yes & Yes \\
\hline
\end{tabular}

Robust standard errors clustered at city level and reported in parentheses. $*<0.1, * * p<0.05, * * * p<0.01$. 
suggest that the coefficients on the number of politics crossed continues to be negative. The coefficients for polities crossed to Aleppo and total polities crossed are also statistically significant. The distance-based capacity measure has the opposite impact depending on the type of route; having clusters of big cities near the trade route towards Aleppo is associated with smaller city size, while the opposite is true for routes to Chang'an. On the combined route, the positive and statistically significant coefficient estimate for the capacity control suggests that having more big cities closer to the trade route is overall beneficial for urbanization. 
Table S5: Effect of Political Fragmentation on City Size, Distance-based State Capacity and Stability Control Variables

\begin{tabular}{|c|c|c|c|c|}
\hline & distance & distance(combined) & distance+local & distance+local(combined \\
\hline Polities to Aleppo & $\begin{array}{c}-0.082^{* *} \\
(0.038)\end{array}$ & & $\begin{array}{l}-0.094^{*} \\
(0.048)\end{array}$ & \\
\hline Polities to Chang'an & $\begin{array}{l}-0.026 \\
(0.036)\end{array}$ & & $\begin{array}{c}0.007 \\
(0.032)\end{array}$ & \\
\hline Non-state territories to Aleppo & $\begin{array}{l}-0.094 \\
(0.106)\end{array}$ & & $\begin{array}{l}-0.099 \\
(0.104)\end{array}$ & \\
\hline Non-state territories to Chang'an & $\begin{array}{c}0.128 \\
(0.112)\end{array}$ & & $\begin{array}{c}0.157 \\
(0.105)\end{array}$ & \\
\hline Polities crossed & & $\begin{array}{c}-0.139^{* * *} \\
(0.050)\end{array}$ & & $\begin{array}{l}-0.089 \\
(0.056)\end{array}$ \\
\hline Non-state territories crossed & & $\begin{array}{c}0.131 \\
(0.147)\end{array}$ & & $\begin{array}{c}0.146 \\
(0.140)\end{array}$ \\
\hline Distance-based capacity (to Aleppo) & $\begin{array}{c}-0.002^{* * *} \\
(0.000)\end{array}$ & & $\begin{array}{c}-0.002^{* * *} \\
(0.000)\end{array}$ & \\
\hline Distance-based capacity (to Chang'an) & $\begin{array}{c}0.013^{* * *} \\
(0.002)\end{array}$ & & $\begin{array}{c}0.012^{* * *} \\
(0.002)\end{array}$ & \\
\hline Distance-based capacity (combined path) & & $\begin{array}{c}0.001^{* * *} \\
(0.000)\end{array}$ & & $\begin{array}{c}0.001^{* * *} \\
(0.000)\end{array}$ \\
\hline Local stability (to Aleppo) & & & $\begin{array}{l}-0.016 \\
(0.198)\end{array}$ & \\
\hline Local stability (to Chang'an) & & & $\begin{array}{c}0.285 \\
(0.264)\end{array}$ & \\
\hline Distant stability (to Aleppo) & & & $\begin{array}{l}-0.509 \\
(0.473)\end{array}$ & \\
\hline Distant stability (to Chang'an) & & & $\begin{array}{c}0.049 \\
(0.376)\end{array}$ & \\
\hline Local stability (combined path) & & & & $\begin{array}{c}0.842^{*} \\
(0.458)\end{array}$ \\
\hline Distant stability (paths from Aleppo/Chang'an) & & & & $\begin{array}{c}0.134 \\
(1.263)\end{array}$ \\
\hline $\mathrm{N}$ & 1,275 & 1,275 & 1,275 & 1,275 \\
\hline Geography X Year & Yes & Yes & Yes & Yes \\
\hline City FE & Yes & Yes & Yes & Yes \\
\hline Year FE & Yes & Yes & Yes & Yes \\
\hline Capital city & Yes & Yes & Yes & Yes \\
\hline Non-state territory & Yes & Yes & Yes & Yes \\
\hline
\end{tabular}

Robust standard errors clustered at city level and reported in parentheses. $* p<0.1, * * p<0.05, * * * p<0.01$. 
S4 Figures 
Figure S1: Largest Eurasian Cities, 1100-1800; "X” indicates Eurasia's urban "center of gravity"
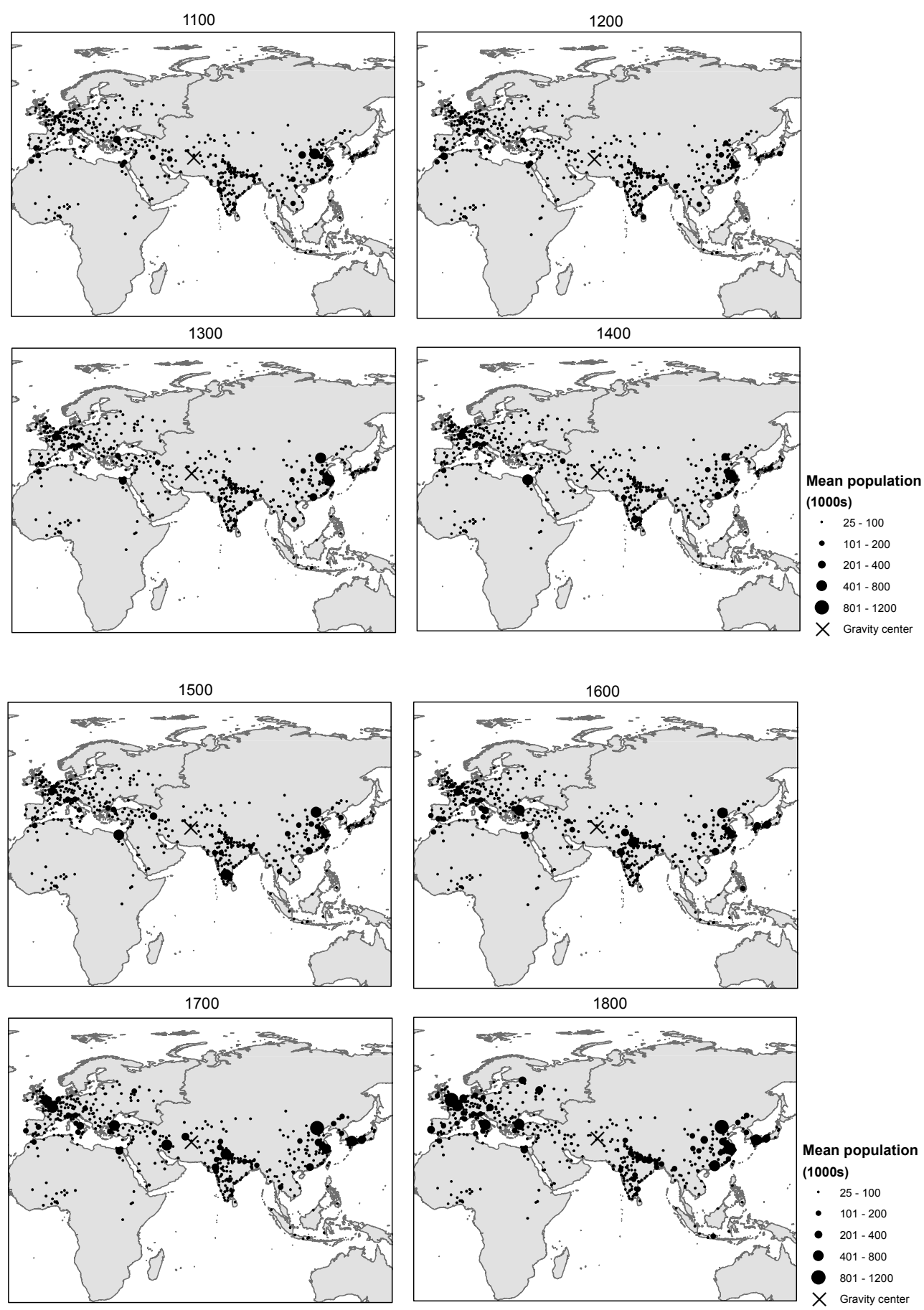
Figure S2: Nomadic Corridors and Silk Roads as identified by Hansen (2012)

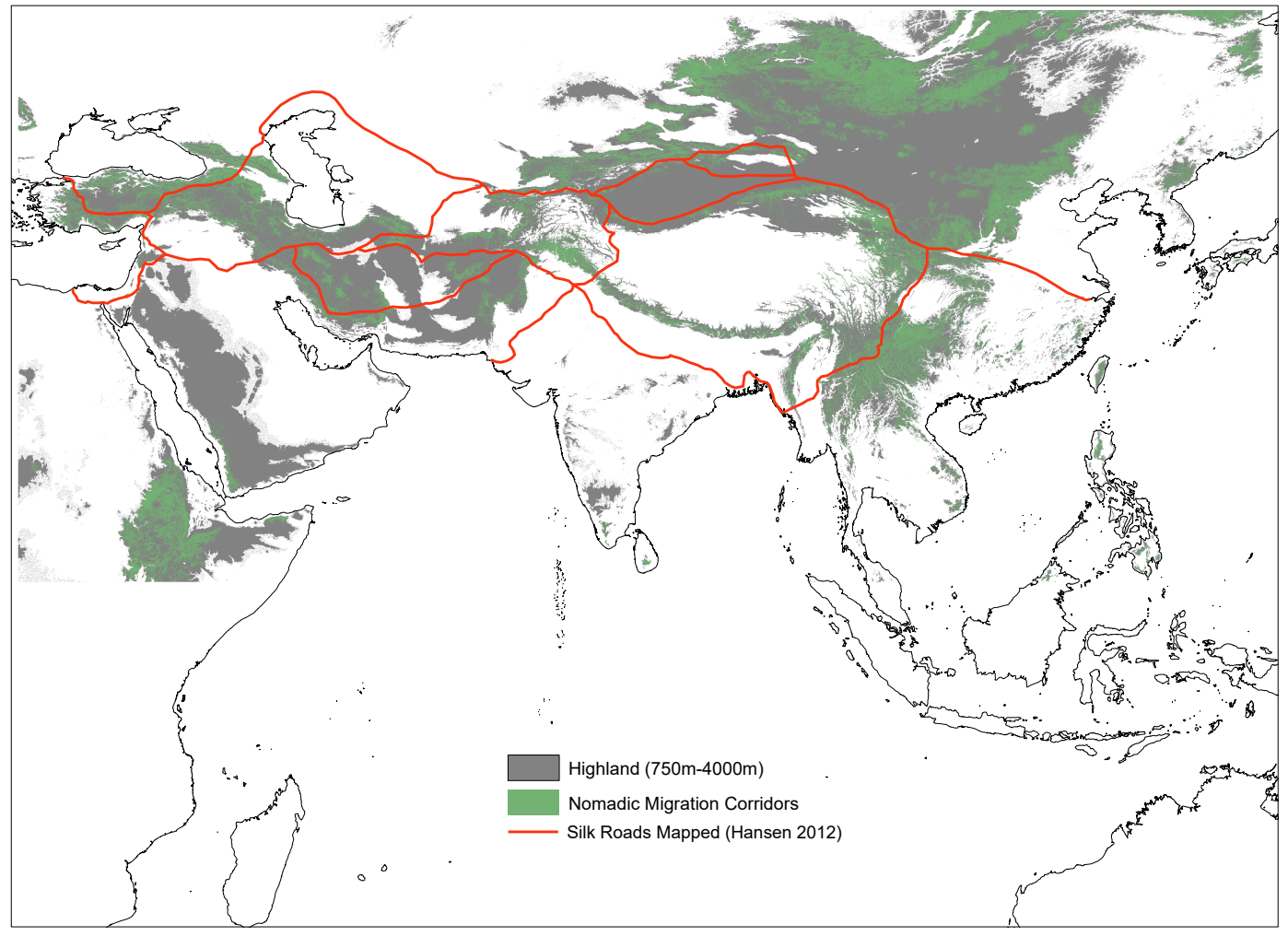




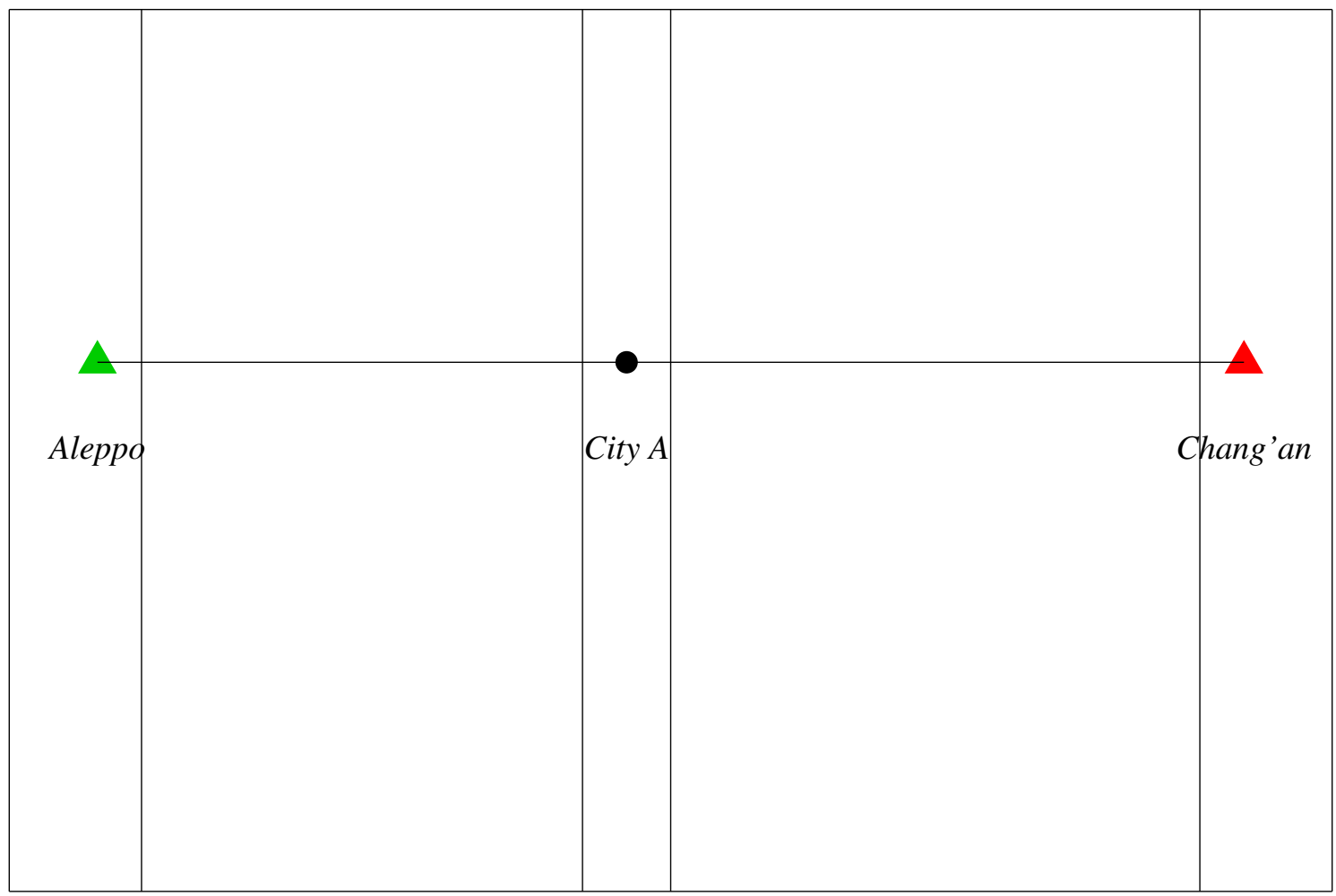

Figure S3: Stylized illustration of localized polity crossings near the origin city vs. faraway crossings near the end destinations (Aleppo and Chang'an). The solid lines represent divisions between polities. 